\title{
Inhibition of adipose tissue lipolysis increases intramuscular lipid and glycogen use in vivo in humans
}

\author{
Citation for published version (APA):
}

van Loon, L. J., Thomason-Hughes, M., Constantin-Teodosiu, D., Koopman, R., Greenhaff, P. L., Hardie, D. G., Keizer, H. A., Saris, W. H., \& Wagenmakers, A. J. M. (2005). Inhibition of adipose tissue lipolysis increases intramuscular lipid and glycogen use in vivo in humans. American Journal of Physiology: Endocrinology and Metabolism, 289(3), E482-493. https://doi.org/10.1152/ajpendo.00092.2005

\section{Document status and date: \\ Published: 01/01/2005}

DOI:

10.1152/ajpendo.00092.2005

\section{Document Version:}

Publisher's PDF, also known as Version of record

\section{Please check the document version of this publication:}

- A submitted manuscript is the version of the article upon submission and before peer-review. There can be important differences between the submitted version and the official published version of record.

People interested in the research are advised to contact the author for the final version of the publication, or visit the DOI to the publisher's website.

- The final author version and the galley proof are versions of the publication after peer review.

- The final published version features the final layout of the paper including the volume, issue and page numbers.

Link to publication

\footnotetext{
General rights rights.

- You may freely distribute the URL identifying the publication in the public portal. please follow below link for the End User Agreement:

www.umlib.nl/taverne-license

Take down policy

If you believe that this document breaches copyright please contact us at:

repository@maastrichtuniversity.nl

providing details and we will investigate your claim.
}

Copyright and moral rights for the publications made accessible in the public portal are retained by the authors and/or other copyright owners and it is a condition of accessing publications that users recognise and abide by the legal requirements associated with these

- Users may download and print one copy of any publication from the public portal for the purpose of private study or research.

- You may not further distribute the material or use it for any profit-making activity or commercial gain

If the publication is distributed under the terms of Article 25fa of the Dutch Copyright Act, indicated by the "Taverne" license above, 


\title{
Inhibition of adipose tissue lipolysis increases intramuscular
}

\author{
lipid and glycogen use in vivo in humans
}

\author{
Luc J. C. van Loon, ${ }^{1,2}$ Michaela Thomason-Hughes, ${ }^{3}$ Dumitru Constantin-Teodosiu, ${ }^{4}$ \\ René Koopman, ${ }^{2}$ Paul L. Greenhaff, ${ }^{4}$ D. Grahame Hardie, ${ }^{3}$ Hans A. Keizer, ${ }^{1}$ \\ Wim H. M. Saris, ${ }^{2}$ and Anton J. M. Wagenmakers ${ }^{5}$ \\ Departments of ${ }^{1}$ Movement Sciences and ${ }^{2}$ Department of Human Biology, Nutrition and Toxicology Research Institute \\ Maastricht, Maastricht University, Maastricht, The Netherlands; ${ }^{3}$ School of Life Sciences, University of Dundee, \\ Dundee, Scotland; ${ }^{4}$ School of Biomedical Sciences, Queen's Medical Centre, University of Nottingham, Nottingham; \\ and ${ }^{5}$ School of Sport and Exercise Sciences, University of Birmingham, Birmingham, United Kingdom
}

Submitted 2 March 2005; accepted in final form 5 May 2005

Van Loon, Luc J. C., Michaela Thomason-Hughes, Dumitru Constantin-Teodosiu, René Koopman, Paul L. Greenhaff, D. Grahame Hardie, Hans A. Keizer, Wim H. M. Saris, and Anton J. M. Wagenmakers. Inhibition of adipose tissue lipolysis increases intramuscular lipid and glycogen use in vivo in humans. Am J Physiol Endocrinol Metab 289: E482-E493, 2005. First published May 10, 2005; doi:10.1152/ajpendo.00092.2005.- This study investigates the consequences of inhibition of adipose tissue lipolysis on skeletal muscle substrate use. Ten subjects were studied at rest and during exercise and subsequent recovery under normal, fasting conditions (control trial, $\mathrm{CON}$ ) and following administration of a nicotinic acid analog (low plasma free fatty acid trial, LFA). Continuous $\left[\mathrm{U}-{ }^{13} \mathrm{C}\right]$ palmitate and $\left[6,6-{ }^{2} \mathrm{H}_{2}\right]$ glucose infusions were applied to quantify plasma free fatty acid (FFA) and glucose oxidation rates and to estimate intramuscular triacylglycerol (IMTG) and glycogen use. Muscle biopsies were collected to measure 1) fiber type-specific IMTG content; 2) allosteric regulators of hormone-sensitive lipase (HSL), glycogen phosphorylase, and pyruvate dehydrogenase; and 3) the phosphorylation status of HSL at $\mathrm{Ser}^{563}$ and $\mathrm{Ser}^{565}$. Administration of a nicotinic acid analog (acipimox) substantially reduced plasma FFA rate of appearance and subsequent plasma FFA concentrations $(P<0.0001)$. At rest, this substantially reduced plasma FFA oxidation rates, which was compensated by an increase in the estimated IMTG use $(P<0.05)$. During exercise, the progressive increase in FFA rate of appearance, uptake, and oxidation was prevented in the LFA trial and matched by greater IMTG and glycogen use. Differential phosphorylation of HSL or relief of its allosteric inhibition by long-chain fatty acyl-CoA could not explain the increase in muscle TG use, but there was evidence to support the contention that regulation may reside at the level of the glucose-fatty acid cycle. This study confirms the hypothesis that plasma FFA availability regulates both intramuscular lipid and glycogen use in vivo in humans.

muscle metabolism; intramyocellular triacylglycerol; fat oxidation; insulin resistance

ELEVATED PLASMA FREE FATTY ACID (FFA) concentrations are associated with obesity and the development of insulin resistance $(38,44)$. Combined with the fact that, in obese and/or type 2 diabetes patients, skeletal muscle shows a reduced capacity to oxidize FFA (20), this likely explains the increased intramyocellular triacylglycerol (IMTG) storage in these subjects $(15,27,53)$. In agreement, various studies have reported a strong relationship between elevated plasma FFA levels, IMTG accretion, and insulin resistance $(22,32,34)$. Insights

Address for reprint requests and other correspondence: L. J. C. van Loon, Dept. of Human Biology, Maastricht Univ., PO Box 616, 6200 MD Maastricht, The Netherlands (e-mail: L.vanLoon@HB.Unimaas.nl). from various lipid infusion studies suggest that elevated plasma FFA delivery and/or impaired fatty acid (FA) oxidation, result in intramyocellular accumulation of triacylglycerol (TG) and FA metabolites (such as fatty acyl-CoA, diacylglycerol, and ceramides), which are likely to induce defects in the insulinsignaling cascade, causing skeletal muscle insulin resistance $(1,3,16,42,65)$.

Insulin resistance can subsequently lead to the development of the hyperglycemic and hyperinsulinemic state that is associated with type 2 diabetes and accompanied by major disturbances in skeletal muscle substrate metabolism $(17,37)$. These disturbances produce a state of metabolic inflexibility that stimulates IMTG storage at the expense of its oxidation (20). Recent data suggest that the structural imbalance between FFA uptake and IMTG storage and its oxidation, and not the actual size or distribution of the IMTG pool, is responsible for the development of skeletal muscle insulin resistance $(10,48,53)$. It could be speculated that greater metabolic flexibility combined with an elevated IMTG turnover rate would prevent excessive accumulation of intramyocellular FA metabolites as well as reduce the degree of lipid peroxidation (42) due to a decreased resident time of the intramyocellular lipids. Therefore, efforts should be made to develop interventions that stimulate IMTG oxidation, which could be of great importance in the prevention and/or treatment of skeletal muscle insulin resistance (52). However, the latter is complicated, as information on the regulation of IMTG metabolism is lacking (17).

Physical exercise stimulates IMTG use $(23,52,54)$ and, as such, represents an effective means to prevent and/or reduce excess IMTG accretion. Recently, we (54) observed a progressive decline in IMTG oxidation rate during prolonged moderate-intensity exercise in healthy trained men. The latter was inversely correlated with a concomitant increase in plasma FFA concentration (54), supporting the contention that elevated plasma FFA levels suppress IMTG oxidation during exercise $(40,41,54,56)$. Consequently, we hypothesised that plasma FFA concentrations regulate the balance between IMTG storage and oxidation. With hormone-sensitive lipase (HSL) (24) as the site at which IMTG mobilization and/or oxidation is likely regulated, we speculated that HSL activity is not only regulated by muscle contraction (25) and adrenalin

The costs of publication of this article were defrayed in part by the payment of page charges. The article must therefore be hereby marked "advertisement" in accordance with 18 U.S.C. Section 1734 solely to indicate this fact. 
$(21,26,59)$, but may also be modified by changes in plasma FFA availability. Indirect evidence for this is provided by the in vitro observation that HSL is inhibited both by oleic acid and oleoyl-CoA in adipose tissue (18). The presence of such a feedback inhibition mechanism in muscle would serve to protect against excessive intracellular accumulation of FA (metabolites) during increased plasma FFA provision. If this hypothesis is correct, reducing plasma FFA provision might reduce intramyocellular FA (metabolite) concentrations, disinhibit HSL, and increase IMTG mobilization and oxidation at rest and/or during prolonged exercise.

In the present study, contemporary stable isotope methodology and fluoresence microscopy were applied to quantify substrate source utilization at rest and during prolonged moderate-intensity exercise under normal fasting conditions (control trial, $\mathrm{CON}$ ) and following specific inhibition of adipose tissue lipolysis, thereby reducing plasma FFA availability (low FFA trial, LFA). In addition, we aimed to elucidate the mechanisms responsible for the anticipated shift in skeletal muscle substrate use. We speculated that an acute reduction in plasma FFA availability modulates skeletal muscle substrate use by way of the Randle cycle, by activating AMP-activated protein kinase (AMPK), by increasing acetyl-CoA carboxylase (ACC) phosphorylation, and/or by stimulating muscle HSL by sitespecific phosphorylation (at $\mathrm{Ser}^{563}$ or $\mathrm{Ser}^{565}$ ). This study provides novel insight into the role of plasma FFA availability as a main factor in modulating IMTG utilization and introduces adipose tissue lipolytic inhibition as a practical intervention to increase both intramuscular lipid and glycogen use at rest and during exercise.

\section{METHODS}

Subjects. Ten fit, active male subjects [age $23 \pm 1 \mathrm{yr}$, height $1.82 \pm$ $0.03 \mathrm{~m}$, body wt $74 \pm 3 \mathrm{~kg}$, fat-free mass $64 \pm 3 \mathrm{~kg}$, maximal power output $\left(\mathrm{W}_{\max }\right) 388 \pm 14 \mathrm{~W}$, and maximal oxygen uptake capacity
$\left(\dot{\mathrm{V}}_{2} \max \right) 62 \pm 3 \mathrm{ml} \cdot \mathrm{kg}$ body $\mathrm{wt}^{-1} \cdot \mathrm{min}^{-1}$ ] were selected to participate in this study. Subjects were informed about the nature and risks of the experimental procedures before their written informed consent was obtained. This study was approved by the local Medical Ethics Committee.

Pretesting. $\mathrm{W}_{\text {max }}$ and $\dot{\mathrm{V}}_{2}$ max were measured on an electronically braked cycle ergometer (Lode Excalibur, Groningen, The Netherlands) during an incremental exhaustive exercise test. Body composition was assessed using the hydrostatic weighing method in the morning after an overnight fast. Body fat percentage was calculated using Siri's equation (46).

Diet and activity before testing. All subjects maintained normal dietary and physical activity patterns throughout the experimental period. In addition, they filled out a food intake diary for 2 days before the first exercise trial to keep their dietary intake as identical as possible before the other trials. The evening before each trial, subjects received the same standardized meal $(41.2 \mathrm{~kJ} / \mathrm{kg}$ body wt, containing 72,11 , and $17 \%$ energy carbohydrate, fat, and protein, respectively).

Experimental trials. Each subject performed three trials separated by at least a 1-wk interval. Each trial consisted of 90 min of resting measurements, followed by $120 \mathrm{~min}$ of cycling exercise $\left(50 \% \mathrm{~W}_{\max }\right)$ and $120 \mathrm{~min}$ of recovery. In the two main trials, a $\left[\mathrm{U}-{ }^{13} \mathrm{C}\right]$ palmitate and a $\left[6,6-{ }^{2} \mathrm{H}_{2}\right]$ glucose tracer were infused continuously at rest and during exercise with breath, blood, and muscle samples collected at regular intervals. In the LFA trial, plasma FFA availability was reduced by oral administration of a peripheral lipolytic inhibitor $(2 \times$ $250 \mathrm{mg}$ acipimox). In the CON trial, a placebo was provided. A third trial was performed to determine the acetate recovery factor to correct $\left[\mathrm{U}-{ }^{13} \mathrm{C}\right]$ palmitate oxidation rates accurately for carbon label retention in the bicarbonate pool(s) and by way of isotopic exchange reactions in the TCA cycle (45).

Protocol. A schematic outline of the study protocol is provided in Fig. 1. After an overnight fast, subjects arrived at the laboratory at 8:00 AM by car or public transportation. After 30 min of supine rest, a percutaneous muscle biopsy was taken from the vastus lateralis muscle. A Teflon catheter (Baxter, Utrecht, The Netherlands) was inserted into an antecubital vein of one arm for blood sampling, and another catheter was inserted in the contralateral arm for isotope

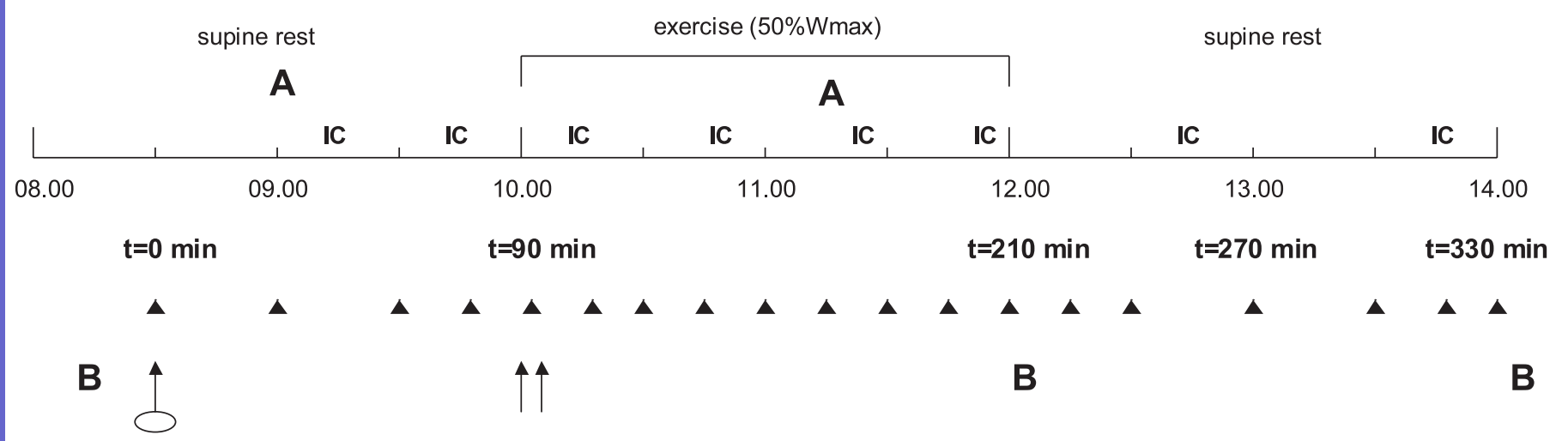

A Acipimox $(250 \mathrm{mg})$ or placebo

IC Indirect calorimetry

- Blood sample $(8 \mathrm{ml})$ and expired breath sample $(10 \mathrm{ml})$

B Muscle biopsy M. vastus lateralis

$\bigcirc\left[{ }^{13} \mathrm{C}\right]$ bicarbonate and $\left[6,6-{ }^{2} \mathrm{H}_{2}\right]$ glucose priming dose

- Continuous infusion $\left[\mathrm{U}^{-13} \mathrm{C}\right]$ palmitate and $\left[6,6-{ }^{2} \mathrm{H}_{2}\right]$ glucose until $\mathrm{t}=210 \mathrm{~min}$

A Doubling $\left[\mathrm{U}^{13} \mathrm{C}\right]$ palmitate infusion rate

Fig. 1. Schematic outline of the study protocol. After initial blood, breath, and muscle biopsy sample, a continuous infusion with $\left[\mathrm{U}-{ }^{13} \mathrm{C}\right]$ palmitate and $\left[6,6-{ }^{2} \mathrm{H}_{2}\right]$ glucose was started for $210 \mathrm{~min}$. At rest and during exercise and postexercise recovery, whole body substrate use was studied under normal fasting conditions (control trial, CON) and under reduced plasma free fatty acid (FFA) availability following administration of the nicotinic acid analog acipimox (low-FFA trial, LFA). 
infusion. Thereafter, a resting blood sample was taken, and expired breath samples were collected into Vacutainer tubes. Subsequently, subjects were administered a single intravenous dose of $\mathrm{NaH}^{13} \mathrm{CO}_{3}$ $(0.06375 \mathrm{mg} / \mathrm{kg})$ to prime the bicarbonate pool(s), followed by a $\left[6,6-{ }^{2} \mathrm{H}_{2}\right]$ glucose prime $(13.5 \mu \mathrm{mol} / \mathrm{kg})$. Thereafter, a continuous infusion of $\left[6,6-{ }^{2} \mathrm{H}_{2}\right]$ glucose $\left(0.3 \mu \mathrm{mol} \mathrm{kg}^{-1} \cdot \mathrm{min}^{-1}\right)$ and $\left[\mathrm{U}^{13} \mathrm{C}\right]$ palmitate $\left(0.01 \mu \mathrm{mol} \mathrm{kg}^{-1} \cdot \mathrm{min}^{-1}\right)\left(\right.$ or $\left[1,2{ }^{13} \mathrm{C}\right]$ acetate in the acetate recovery trial) was started $(t=0 \mathrm{~min})$ via a calibrated IVAC pump (IVAC 560, San Diego, CA) and continued for $210 \mathrm{~min}$. At $t=0 \mathrm{~min}$ and $t=165 \mathrm{~min}$, a capsule containing $250 \mathrm{mg}$ of acipimox (Nedios, Byk, Zwanenburg, The Netherlands) or a placebo was orally administered. At $t=90 \mathrm{~min}$, subjects started to exercise on a cycle ergometer at a workload of $50 \% \mathrm{~W}_{\max }$ for a 120 -min period. While subjects were at rest, $\dot{\mathrm{V}}_{2}$ and $\dot{\mathrm{V}}_{\mathrm{CO}_{2}}$ were measured continuously (Oxycon- $\beta$, Mijnhart); during exercise $\dot{\mathrm{V}}_{2}$ and $\dot{\mathrm{V}}_{\mathrm{CO}_{2}}$ were measured for 5 min every $15 \mathrm{~min}$ before sampling of blood and expired breath. Immediately after cessation of exercise, a second muscle biopsy was taken, after which the subjects rested supine for 120 min during which $\dot{\mathrm{V}}_{2}$ and $\dot{\mathrm{V}}_{\mathrm{CO}_{2}}$ were again measured continuously. After $120 \mathrm{~min}$ of postexercise recovery, a third muscle biopsy was taken. Breath and blood samples were collected at $t=0,30,60,75$, and $90 \mathrm{~min}$ (at rest) and at $t=105,120,135,150,165,180,195$, and 210 min (during exercise). In addition, blood samples were collected at $t=225,240$, 270, 300, 315, and 330 min (during postexercise recovery).

Tracer infusion. Infusion rates of $\left[\mathrm{U}_{-}{ }^{13} \mathrm{C}\right]$ palmitate and $[6,6-$ $\left.{ }^{2} \mathrm{H}_{2}\right]$ glucose averaged $9.3 \pm 0.2$ and $276.1 \pm 4.3 \mathrm{nmol} \cdot \mathrm{kg}^{-1} \cdot \mathrm{min}^{-1}$, respectively. At the onset of exercise $\left[\mathrm{U}_{-}{ }^{13} \mathrm{C}\right]$ palmitate infusion rates were doubled $\left(18.6 \pm 0.4 \mathrm{nmol} \cdot \mathrm{kg}^{-1} \cdot \mathrm{min}^{-1}\right)$. In the acetate recovery trial, a corresponding amount of ${ }^{13} \mathrm{C}$ was infused, resulting in an average $\left[1,2-{ }^{13} \mathrm{C}\right]$ acetate infusion rate of $71.2 \pm 1.6$ and $142.4 \pm 3.1$ $\mathrm{nmol} \cdot \mathrm{kg}^{-1} \cdot \mathrm{min}^{-1}$ at rest and during exercise, respectively. Palmitate, glucose, and acetate tracer concentrations in the infusates averaged $1.06 \pm 0.02,21.3 \pm 0.6$, and $4.64 \pm 0.10 \mathrm{mmol} / \mathrm{l}$, respectively.

Blood and breath sample analysis. Blood samples $(7 \mathrm{ml})$ were collected in EDTA-containing tubes and centrifuged at 1,000 $\mathrm{g}$ for 10 min at $4^{\circ} \mathrm{C}$. Aliquots of plasma were frozen immediately in liquid nitrogen and stored at $-80^{\circ} \mathrm{C}$. Plasma glucose (Uni Kit III; Roche, Basel, Switzerland), lactate (11), FFA (NEFA-C; Wako Chemicals, Neuss, Germany), free glycerol (148270; Roche Diagnostics, Indianapolis, IN), and triglyceride (GPO-Trinder 337B; Sigma Diagnostics, St Louis, MO) concentrations were analyzed with a COBAS semiautomatic analyzer (Roche).

Expired-breath samples were analyzed for ${ }^{13} \mathrm{C} /{ }^{12} \mathrm{C}$ ratio by gas chromatography-continuous flow isotope ratio mass spectrometry (GC-IRMS; Finnigan MAT 252, Bremen, Germany). For determination of plasma palmitate and FFA kinetics, FFA were extracted from plasma, isolated by thin-layer chromatography, and derivatized to their methyl esters. Palmitate concentration was determined on an analytic gas chromatograph with flame ionization detection using heptadecanoic acid as an internal standard and on average comprised $22.9 \pm 1.0 \%$ of total FFA. Isotope tracer-to-tracee ratio (TTR) of $\left[\mathrm{U}-{ }^{13} \mathrm{C}\right]$ palmitate was determined using GC-combustion-IRMS (Finnigan MAT 252). After derivatization, plasma $\left[6,6-{ }^{2} \mathrm{H}_{2}\right]$ glucose enrichment was determined by electron ionization GC-MS (Finnigan INCOS-XL). Glucose (Uni Kit III, Roche) and acetate (Kit 148261, Boehringer) concentrations in the infusates were determined with the COBAS FARA.

Calculations. From respiratory measurements, total fat and carbohydrate oxidation rates were calculated using the nonprotein respiratory quotient (33).

$$
\text { fat oxidation rate }=1.695 \dot{\mathrm{VO}}_{2}-1.701 \dot{\mathrm{V}}_{\mathrm{CO}_{2}}
$$

$$
\text { carbohydrate oxidation rate }=4.585 \mathrm{~V}_{\mathrm{CO}_{2}}-3.226 \dot{\mathrm{VO}}_{2}
$$

with $\dot{\mathrm{VO}}_{2}$ and $\dot{\mathrm{V}}_{2}$ in liters per minute and oxidation rates in grams per minute. Breath and plasma enrichments are expressed as TTR:

$$
\text { TTR }=\left({ }^{13} \mathrm{C} /{ }^{12} \mathrm{C}\right)_{\mathrm{sa}}-\left({ }^{13} \mathrm{C} /{ }^{12} \mathrm{C}\right)_{\mathrm{bk}}
$$

in which sa indicates sample and bk indicates background value. Rates of palmitate and glucose appearance $\left(R_{a}\right)$ and disappearance $\left(R_{d}\right)$ were calculated using the single-pool non-steady-state Steele equations adapted for stable isotope methodology, as described elsewhere (63). As such, plasma palmitate and glucose $\mathrm{R}_{\mathrm{d}}$ were calculated by correcting the $R_{a}$ for the time-dependent changes in plasma metabolite concentration.

$$
\begin{gathered}
\mathrm{R}_{\mathrm{a}}=\frac{\mathrm{F}-\mathrm{V}\left[\left(\mathrm{C}_{2}+\mathrm{C}_{1}\right) / 2\right]\left[\left(\mathrm{E}_{2}-\mathrm{E}_{1}\right) /\left(t_{2}-t_{1}\right)\right]}{\left(\mathrm{E}_{2}+\mathrm{E}_{1}\right) / 2} \\
\mathrm{R}_{\mathrm{d}}=\mathrm{R}_{\mathrm{a}}-\mathrm{V} \cdot\left(\frac{\mathrm{C}_{2}-\mathrm{C}_{1}}{t_{2}-t_{1}}\right)
\end{gathered}
$$

where $\mathrm{F}$ is the infusion rate $\left(\mu \mathrm{mol} \cdot \mathrm{kg}^{-1} \cdot \mathrm{min}^{-1}\right) ; \mathrm{V}=$ distribution volume for palmitate or glucose (40 and $160 \mathrm{ml} / \mathrm{kg}$, respectively); $\mathrm{C}_{1}$ and $\mathrm{C}_{2}$ are the palmitate or glucose concentrations $(\mathrm{mmol} / \mathrm{l})$ at times $I\left(t_{1}\right)$ and $2\left(t_{2}\right)$, respectively, and $\mathrm{E}_{2}$ and $\mathrm{E}_{1}$ are the plasma palmitate or glucose enrichments (TTR) at $t_{1}$ and $t_{2}$, respectively. ${ }^{13} \mathrm{CO}_{2}$ production $\left(\operatorname{Pr}^{13} \mathrm{CO}_{2}, \mathrm{~mol} / \mathrm{min}\right)$ from the infused palmitate tracer was calculated as

$$
\operatorname{Pr}^{13} \mathrm{CO}_{2}=\left(\mathrm{TTR}_{\mathrm{co}_{2}} \cdot \dot{\mathrm{V}} \mathrm{CO}_{2}\right) /(k \cdot \mathrm{Ar})
$$

where TTR $\mathrm{CO}_{2}$ is the breath ${ }^{13} \mathrm{C} /{ }^{12} \mathrm{C}$ ratio at a given time point, $\dot{\mathrm{V}}_{\mathrm{CO}_{2}}$ is carbon dioxide production $(1 / \mathrm{min}), k$ is the volume of $1 \mathrm{~mol}$ of $\mathrm{CO}_{2}$ (22.4 1/min), and Ar is the fractional ${ }^{13} \mathrm{C}$ label recovery in breath $\mathrm{CO}_{2}$, observed after the infusion of labeled acetate (45) and calculated as

$$
\mathrm{Ar}=\left(\left(\mathrm{TTR}_{\mathrm{Co}_{2}} \cdot \dot{\mathrm{V}} \mathrm{CO}_{2}\right) /(k \cdot 2 \mathrm{~F})\right)
$$

where $\mathrm{F}$ is infusion rate of $\left[1,2-{ }^{13} \mathrm{C}\right]$ acetate $(\mathrm{mol} / \mathrm{min})$. Plasma palmitate oxidation $\left(\mathrm{R}_{\mathrm{ox}}, \mathrm{mol} / \mathrm{min}\right)$ can subsequently be calculated as

$$
\mathrm{R}_{\mathrm{ox}} \text { palmitate }=\mathrm{R}_{\mathrm{d}} \text { palmitate } \cdot\left(\operatorname{Pr}^{13} \mathrm{CO}_{2} / \mathrm{F} \cdot 16\right)
$$

where $R_{d}$ palmitate is the rate of palmitate disappearance ( $\mathrm{mol} / \mathrm{min}$ ); $\mathrm{F}$ is the palmitate infusion rate $(\mathrm{mol} / \mathrm{min})$, and 16 is the number of carbon atoms in palmitate. Total plasma FFA oxidation was calculated by dividing palmitate oxidation rates by the fractional contribution of plasma palmitate to total plasma FFA concentration. Muscle-derived TG use was estimated by subtracting plasma FFA oxidation from total fat oxidation. However, it should be noted that the indirect stable isotope methodology does not differentiate between muscle- or lipoprotein-derived TG use. However, the contribution of lipoproteinderived TG oxidation to total energy expenditure is assumed to be of relatively minor quantitative importance, especially in an overnight fasted state (52).

In a previous study, where we applied both $\left[\mathrm{U}-{ }^{13} \mathrm{C}\right]-$ and $[6,6-$ ${ }^{2} \mathrm{H}_{2}$ ] glucose tracers (19) during moderate intensity exercise, it was shown that the percentage of plasma glucose $R_{d}$ that was oxidized varied between 96 and $100 \%$. Therefore, plasma glucose oxidation rate during exercise was calculated as

$$
\mathrm{R}_{\mathrm{ox}} \text { plasma glucose }=\mathrm{R}_{\mathrm{d}} \text { plasma glucose }
$$

Muscle glycogen oxidation was calculated by subtracting plasma glucose oxidation from total carbohydrate oxidation.

Muscle sample analyses. Muscle samples were freed from any visible nonmuscle material and rapidly frozen in liquid nitrogen. About $15 \mathrm{mg}$ of each muscle sample were frozen in liquid nitrogencooled isopentane and embedded in Tissue-Tek (Sakura Finetek, Zoeterwoude, The Netherlands). Multiple serial sections $(5 \mu \mathrm{m})$ from biopsy samples were thaw mounted together on uncoated, precleaned glass slides for each subject and stained with Oil Red O together with immunolabeled cellular constituents by use of the protocol described before (53-55). The applied epifluorescence technique represents a semiquantitative method that can be used to compare fiber type- 
specific intramyocellular lipid content between muscle cross sections (53-55).

About 15-20 mg of each muscle biopsy sample were freeze-dried, dissected free from visible blood and connective tissue, and powdered. About $10 \mathrm{mg}$ of muscle powder were then extracted with $0.5 \mathrm{M}$ perchloric acid containing $1 \mathrm{mM}$ EDTA. After centrifugation, the supernatant was neutralized with $2.2 \mathrm{M} \mathrm{KHCO}_{3}$ and used for determination of muscle phosphocreatine, free creatine (13), citrate (2), lactate (13), glycogen, glucose 6-phosphate, free carnitine, acetylcarnitine, long-chain fatty acylcarnitine, long-chain fatty acyl-CoA, $\mathrm{CoASH}$, and acetyl-CoA (5) concentrations. Except for muscle lactate, glycogen, and citrate, all these concentrations were corrected for muscle total creatine content within each subject.

Another piece of muscle sample $(20 \mathrm{mg})$ was ground to a fine powder under liquid nitrogen and homogenized in $200 \mu \mathrm{l}$ of ice-cold buffer, as described previously (8). For measurement of AMP-activated protein kinase (AMPK) activity, muscle lysates containing 100 $\mu \mathrm{g}$ of protein were immunoprecipitated using $10 \mu \mathrm{g}$ of sheep anti- $\alpha 1-$ plus $10 \mu \mathrm{g}$ of anti- $\alpha 2$-AMPK coupled to protein G-Sepharose before a standard AMPK assay was performed using AMARA-peptide (AMARAASAAA-LARRR) as a substrate (12). HSL $\mathrm{Ser}^{563}$ and $\mathrm{Ser}^{565}$ phosphorylation, acetyl-CoA carboxylase (ACC) $\mathrm{Ser}^{221}$ phosphorylation, and total ACC expression were measured in muscle lysates containing $20 \mu \mathrm{g}$ of protein by SDS-PAGE followed by Western blotting onto nitrocellulose (64). Membranes were probed with affinity-purified antibodies as follows: anti-HSL phospho-Ser ${ }^{563}$ $(0.2 \mu \mathrm{g} / \mathrm{ml})$, anti-HSL phospho-Ser ${ }^{565}(0.06 \mu \mathrm{g} / \mathrm{ml})$, anti-ACC phospho-Ser ${ }^{221}(1 \mu \mathrm{g} / \mathrm{ml})$. Antibody binding was detected using the LiCor Odyssey IR imaging system, which uses near-infrared (IR) fluorescent dyes for detection of proteins. Briefly, membranes were incubated with donkey anti-sheep IgG labeled with IRDye 680 (Molecular Probes) for $1 \mathrm{~h}$ before being imaged. ACC expression was determined using streptavidin labeled with IRDye 800 (Rockland Immunochemicals). The sheep anti- $\alpha 1$, anti- $\alpha 2$, and phosphospecific ACC antibodies have been described previously $(14,64)$. Sheep phosphospecific HSL antibodies against $\operatorname{Ser}^{565}$ and $\operatorname{Ser}^{563}$ were raised against synthetic peptides CTESMRRSVSpEAALAQP and CTESMRRSpVSEAALAQP, respectively (residues 556-571 of rat skeletal muscle HSL with cysteine at the $\mathrm{NH}_{2}$ terminus for coupling), using methods previously described (47).

Statistics. All data are expressed as means \pm SE. To compare tracer kinetics, substrate utilization rates, IMTG contents, and/or plasma metabolite concentrations over time between trials, a two-way repeated-measures analysis of variance (ANOVA) was applied. Scheffé's post hoc test was applied in case of a significant $F$-ratio to locate specific differences. For non-time-dependent variables, a Student's $t$-test for paired observations was used. Significance was set at the 0.05 level of confidence.

\section{RESULTS}

Tracer kinetics. Plasma FFA and glucose concentrations at rest, exercise, and postexercise recovery under normal fasting conditions (CON) and reduced plasma FFA availability (LFA) are shown in Fig. 2. Because plasma concentrations varied over time in the LFA and/or CON trial, non-steady-state Steele equations were applied to calculate tracer kinetics. Plasma glucose $R_{a}$ and $R_{d}$ were significantly higher during exercise compared with resting values in both the CON and LFA trials (Table 1), with $\mathrm{R}_{\mathrm{a}}$ and $\mathrm{R}_{\mathrm{d}}$ being increased over time during exercise (Fig. 3A; $P<0.001$ ). No differences in plasma glucose kinetics were observed between trials. In the CON trial, plasma palmitate $\mathrm{R}_{\mathrm{a}}, \mathrm{R}_{\mathrm{d}}$, and $\mathrm{R}_{\mathrm{ox}}$ were significantly higher during exercise compared with resting values (Table 1), with $\mathrm{R}_{\mathrm{a}}, \mathrm{R}_{\mathrm{d}}$, and $\mathrm{R}_{\mathrm{ox}}$ being increased over time (Fig. $3 B ; P<$ 0.001). In the LFA trial, plasma palmitate $R_{a}$ and $R_{d}$ were similar at rest and during exercise, with only $\mathrm{R}_{\mathrm{ox}}$ being significantly greater during exercise compared with resting values $(P<0.001$; Table 1$)$. No changes in plasma palmitate $\mathrm{R}_{\mathrm{a}}, \mathrm{R}_{\mathrm{d}}$, and $\mathrm{R}_{\mathrm{ox}}$ were observed over time (Fig. $3 B$ ). Both at rest and during exercise, plasma palmitate $\mathrm{R}_{\mathrm{a}}, \mathrm{R}_{\mathrm{d}}$, and $\mathrm{R}_{\mathrm{ox}}$ were substantially lower in the LFA trial than in the CON trial $(P<$ 0.005; Table 1 and Fig. 3).

Plasma metabolite concentrations. Plasma FFA, glycerol, TG, glucose, and lactate concentrations are shown in Fig. 2. Plasma FFA concentrations in the CON trial increased throughout the exercise period, reaching peak levels at $15 \mathrm{~min}$ after cessation of exercise. Thereafter, plasma FFA concentrations declined but remained well above preexercise resting levels $(P<0.0001)$. In contrast, plasma FFA concentrations in the LFA trial decreased during exercise but increased gradually toward preexercise levels during recovery $(P<0.0001)$. At all time points, plasma FFA concentrations were significantly lower in the LFA than in the CON trial $(P<0.001)$. Plasma glycerol concentrations increased significantly during exercise and decreased during postexercise recovery in both trials $(P<$ 0.001). At all time points, free glycerol concentrations were significantly lower in the LFA than in the CON trial $(P<$ $0.0001)$. Plasma TG decreased gradually during exercise in both trials $(P<0.0001)$, with a tendency to increase during recovery in the CON trial. Nevertheless, plasma TG levels were not significantly different between trials. Plasma glucose concentrations significantly declined during exercise in both trials $(P<0.0001)$, with no further changes during recovery. Plasma lactate concentrations had increased well above preexercise resting levels within the first $15 \mathrm{~min}$ of exercise, after which plasma lactate concentrations declined throughout the remaining experimental time in both trials $(P<0.0001)$. However, plasma lactate concentrations during recovery were significantly greater in the LFA than in the CON trial $(P<0.05)$.

Substrate utilization. Energy expenditure and substrate source utilization rates at rest are shown in Fig. 4A. Energy expenditure was similar between trials and averaged $5.54 \pm$ 0.23 and $5.26 \pm 0.24 \mathrm{~kJ} / \mathrm{min}$, respectively. However, substrate source utilization significantly differed between trials $(P<$ 0.05). Total fat oxidation rate averaged $0.09 \pm 0.01$ and $0.07 \pm$ $0.01 \mathrm{~g} / \mathrm{min}$, contributing $64 \pm 4$ and $53 \pm 4 \%$ to energy expenditure, in the CON and LFA trials, respectively $(P<$ $0.01)$. The apparent difference in total fat oxidation was entirely accounted for by a $38 \pm 7 \%$ reduction in plasma FFA oxidation rate in the LFA compared with the CON trial $(0.04 \pm$ 0.004 and $0.07 \pm 0.006 \mathrm{~g} / \mathrm{min}$, respectively; $P<0.01)$. In contrast, estimated IMTG oxidation rates were substantially augmented in the LFA compared with the CON trial $(0.029 \pm$ 0.005 vs. $0.017 \pm 0.006 \mathrm{~g} / \mathrm{min}$, respectively; $P<0.05)$. Carbohydrate oxidation rates were significantly higher in the LFA compared with the CON trial, and averaged $0.15 \pm 0.01$ and $0.12 \pm 0.02 \mathrm{~g} / \mathrm{min}$, respectively.

In the subsequent exercise trial, the applied $50 \% \mathrm{~W}_{\max }$ workload averaged $194 \pm 7 \mathrm{~W}$, corresponding to $59 \pm 1 \%$ of $\dot{\mathrm{V}}_{2}$ max. Energy expenditure and endogenous substrate source utilization during exercise are illustrated in Figs. $4 B$ and 5. In the CON trial, total fat oxidation rate increased significantly during exercise and was matched by a decrease in total carbohydrate oxidation $(P<0.001)$. The increase in total fat oxidation rate during exercise in the $\mathrm{CON}$ trial, which occurred 
despite the progressive decline in IMTG- plus lipoproteinderived TG oxidation, was entirely accounted for by an increase in plasma FFA oxidation rate $(P<0.001 ;$ Fig. $5, A$ and $B)$. The decrease in total carbohydrate oxidation rate during exercise in the CON trial was fully accounted for by the gradual decrease in muscle glycogen use, whereas plasma glucose oxidation rates significantly increased over time $(P<$ 0.0001; Fig. 5, $C$ and $D$ ). In contrast to the CON trial, total fat
A

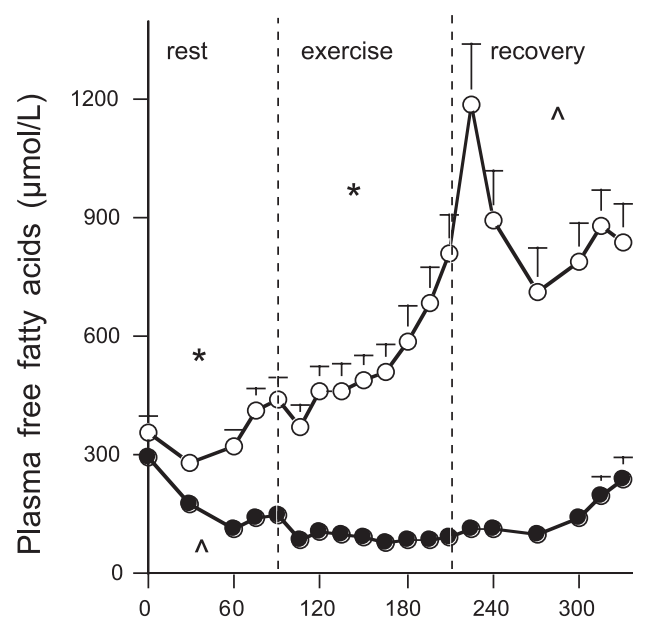

C

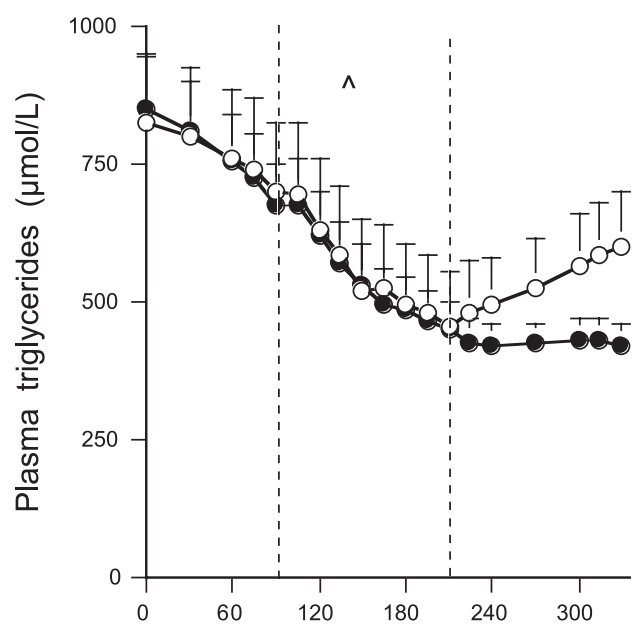

E

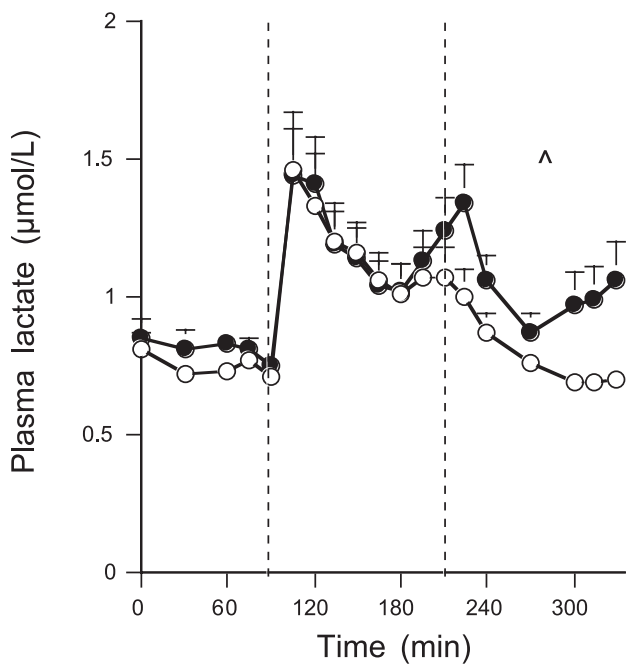

B

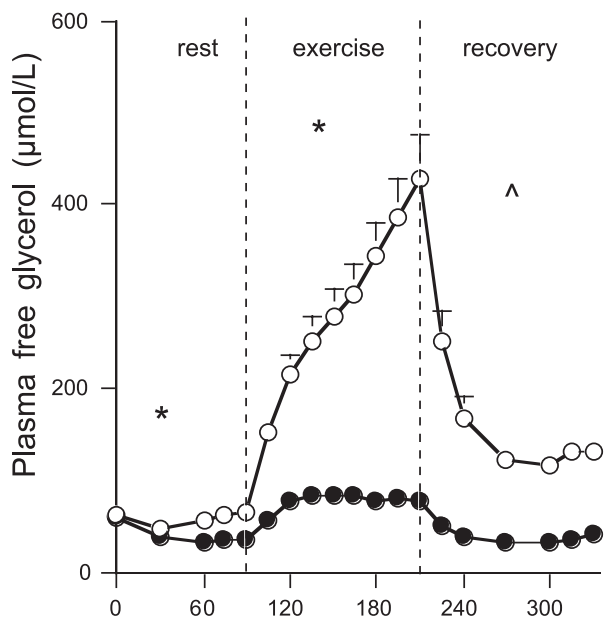

D

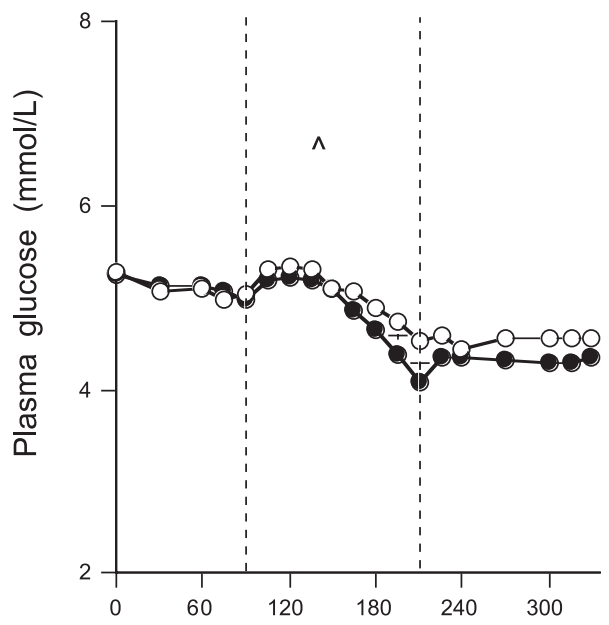

Fig. 2. Plasma metabolite concentrations at rest, during prolonged submaximal exercise, and during $2 \mathrm{~h}$ of postexercise recovery in CON and LFA trials. Data provided are means \pm SE. *Significant increase over time within resting, exercise, and/or postexercise recovery period; ^significant decrease over time within resting, exercise, and/or postexercise recovery period $(P<0.05)$. 
Table 1. Tracer kinetics at rest and during exercise

\begin{tabular}{lcc}
\hline \hline & $\begin{array}{c}\text { Control Trial } \\
(\mathrm{CON})\end{array}$ & $\begin{array}{c}\text { Low FFA Availability } \\
(\text { LFA })\end{array}$ \\
\hline Rest & & \\
Palmitate & \\
$\mathrm{R}_{\mathrm{a}}$ & $2.34 \pm 0.22$ & $1.41 \pm 0.15 \dagger$ \\
$\mathrm{R}_{\mathrm{d}}$ & $2.30 \pm 0.22$ & $1.40 \pm 0.14 \dagger$ \\
$\mathrm{R}_{\mathrm{ox}}$ & $0.81 \pm 0.09$ & $0.45 \pm 0.06 \dagger$ \\
$\% \mathrm{R}_{\mathrm{a} \text { ox }}$ & $34.3 \pm 1.78$ & $31.3 \pm 1.81$ \\
Glucose & & \\
$\mathrm{R}_{\mathrm{a}}$ & $15.8 \pm 1.0$ & $15.2 \pm 0.7$ \\
$\mathrm{R}_{\mathrm{d}}$ & $16.0 \pm 1.0$ & $15.8 \pm 0.7$ \\
Exercise & & \\
Palmitate & & $1.52 \pm 0.09 \dagger$ \\
$\mathrm{R}_{\mathrm{a}}$ & $5.28 \pm 0.57^{*}$ & $1.51 \pm 0.09 \dagger$ \\
$\mathrm{R}_{\mathrm{d}}$ & $5.23 \pm 0.56^{*}$ & $1.20 \pm 0.08^{* \dagger}$ \\
$\mathrm{R}_{\mathrm{ox}}$ & $4.80 \pm 0.48^{*}$ & $79.7 \pm 2.90^{*} \dagger$ \\
$\% \mathrm{R}_{\mathrm{a}}$ ox & $92.0 \pm 3.04^{*}$ & \\
Glucose & & $32.4 \pm 3.3^{*}$ \\
$\mathrm{R}_{\mathrm{a}}$ & $31.8 \pm 1.8^{*}$ & $33.9 \pm 3.4^{*}$ \\
$\mathrm{R}_{\mathrm{d}}$ & $33.0 \pm 1.9^{*}$ & \\
\hline
\end{tabular}

Values are expressed as means $\pm \mathrm{SE} ; n=8$ subjects. Tracer kinetics as calculated at rest and averaged during $2 \mathrm{~h}$ of exercise at $50 \% \mathrm{~W}_{\max } . \mathrm{R}_{\mathrm{a}}$, rate of appearance; $\mathrm{R}_{\mathrm{d}}$, rate of disappearance; $\mathrm{R}_{\mathrm{ox}}$, rate of oxidation $\left(\mu \mathrm{mol} \cdot \mathrm{kg}^{-1} \cdot \mathrm{min}^{-1}\right) ; \% \mathrm{R}_{\text {a ox }}, \% \mathrm{R}_{\mathrm{a}}$ palmitate oxidized. $*$ Significantly different from resting values $(P<0.001)$; † significantly different between trials $(P<$ $0.01)$.

and carbohydrate oxidation rates remained stable during exercise in the LFA trial. Total fat oxidation rates were significantly lower in the LFA trial compared with the CON trial $(P<0.0001)$. This was entirely due to lower plasma FFA oxidation rates in the LFA trial $(P<0.0001$; Fig. 5A). Estimated IMTG oxidation rates remained stable throughout exercise in the LFA trial and did not decline as shown in the CON trial $(P<0.0001)$. The latter resulted in significantly greater muscle-derived TG use in the LFA compared with the CON trial (Fig. 5B). Carbohydrate oxidation rates were substantially higher in the LFA compared with the CON trials $(P<0.001)$. Plasma glucose oxidation rates increased continuously during exercise $(P<0.0001)$ and were similar to those observed in the CON trial (Fig. $5 C$ ). Therefore, the greater carbohydrate oxidation rate in the LFA trial was entirely attributed to the greater muscle glycogen use in the LFA trial (Fig. 5D), which gradually declined during exercise similarly to the observations in the CON trial $(P<0.0001)$.

Average substrate source utilization, calculated over the second hour of exercise, is illustrated in Fig. 4B. Total fat oxidation averaged $0.61 \pm 0.04$ and $0.39 \pm 0.03 \mathrm{~g} / \mathrm{min}$, representing $43 \pm 4$ and $28 \pm 2 \%$ of total energy expenditure in the CON and LFA trials, respectively $(P<0.001)$. In the CON trial, plasma FFA oxidation provided $30 \pm 3 \%$ of total energy expenditure, with muscle and plasma lipoprotein-derived TG use contributing $13 \pm 1 \%$. With low plasma FFA availability in the LFA trial, plasma FFA oxidation was substantially impaired, providing only $9 \pm 1 \%$ of energy expenditure. In contrast, IMTG oxidation was significantly augmented in the LFA trial, providing $19 \pm 2 \%$ of total energy expenditure. Total carbohydrate oxidation rates averaged $1.98 \pm 0.13$ and $2.54 \pm 0.10 \mathrm{~g} / \mathrm{min}$ in the CON and LFA trials, respectively $(P<0.01)$. The greater carbohydrate oxidation rate in the LFA trial was fully attributed to an increase in muscle glycogen use $(P<0.01)$, whereas plasma glucose oxidation rates did not differ between trials.

Resting energy expenditure was significantly increased in both trials during postexercise recovery compared with preexercise values $(6.1 \pm 0.3$ and $5.7 \pm 0.2 \mathrm{~kJ} / \mathrm{min}$ in the $\mathrm{CON}$ and LFA trials, respectively). In the CON trial, this was entirely attributed to a greater total fat oxidation rate compared with preexercise resting values, with a concomitant decrease in carbohydrate use $(P<0.001)$. In the LFA trial, the higher energy expenditure during recovery was fully accounted for by a greater total carbohydrate oxidation rate. In line with preexercise measurements, absolute as well as relative fat oxidation rates were significantly higher in the $\mathrm{CON}$ trial compared with the LFA trial during recovery $(P<0.001)$.

Muscle tissue analysis. Muscle tissue analysis for IMTG content using semiquantitative fluorescence microscopy on Oil Red O-stained muscle cross sections showed a significant decline in type I muscle fiber lipid content in both trials $(P<$ 0.01 ; Fig. 6). The net decline in type I fiber lipid content was
A

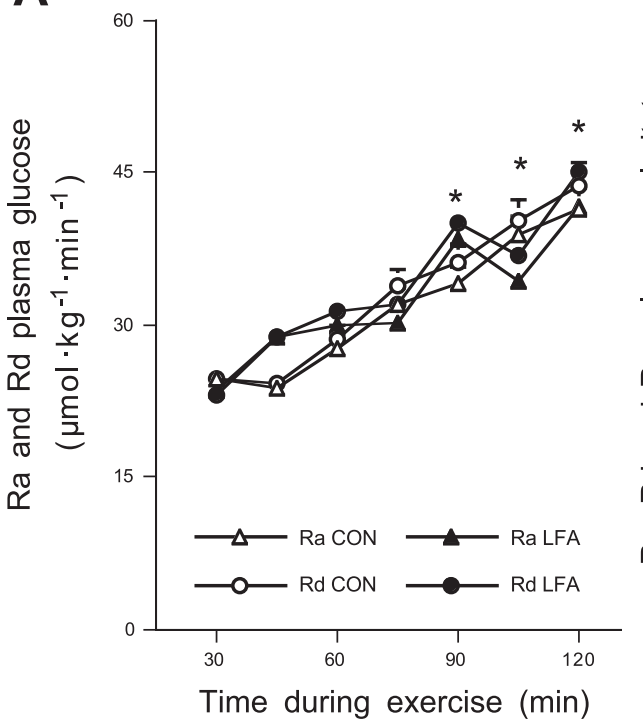

B

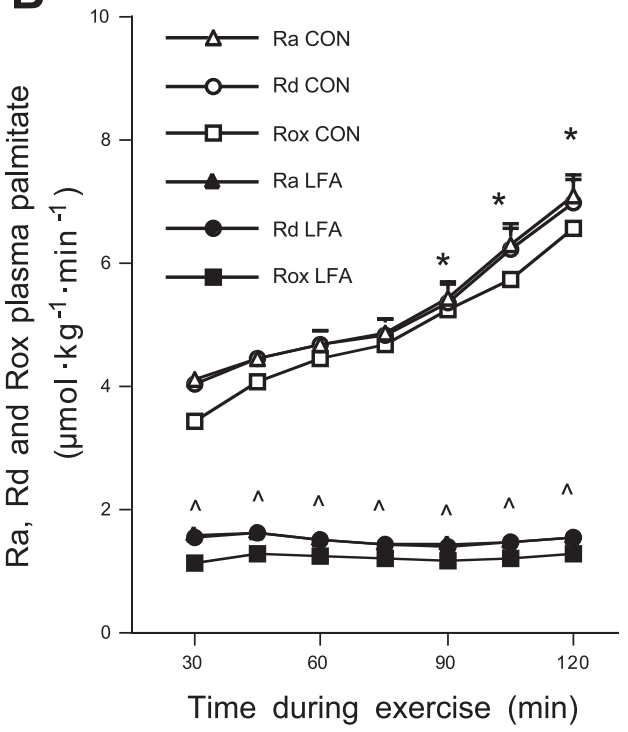

Fig. 3. Plasma glucose rate of appearance $\left(\mathrm{R}_{\mathrm{a}}\right)$ and disappearance $\left(\mathrm{R}_{\mathrm{d}}\right)(A)$ and plasma palmitate $\mathrm{R}_{\mathrm{a}}, \mathrm{R}_{\mathrm{d}}$, and rate of oxidation $\left(\mathrm{R}_{\mathrm{ox}}\right)$ $(B)$ during prolonged submaximal endurance exercise under normal fasting conditions $(\mathrm{CON})$ and following administration of a peripheral lipolytic inhibitor (LFA) (in $\mu \mathrm{mol} \cdot \mathrm{kg}^{-1} \cdot \min ^{-1}$ ). Plasma glucose $R_{a}$ and $\mathrm{R}_{\mathrm{d}}$ substantially increased during exercise in both trials $(P<0.0001)$. Plasma palmitate $\mathrm{R}_{\mathrm{a}}, \mathrm{R}_{\mathrm{d}}$, and $\mathrm{R}_{\mathrm{ox}}$ significantly increased during exercise in the CON trial $(P<0.0001)$, whereas in the LFA trial $R_{a}, R_{d}$, and $R_{o x}$ remained stable over time at a substantially lower value $(P<0.0001)$. Data are means \pm SE. * Significantly higher compared with values at $t=30 \mathrm{~min}$ within each trial $(P<$ $0.05)$; ^significant difference in $\mathrm{R}_{\mathrm{a}}, \mathrm{R}_{\mathrm{d}}$, and $\mathrm{R}_{\mathrm{ox}}$ between trials $(P<0.0001)$. 

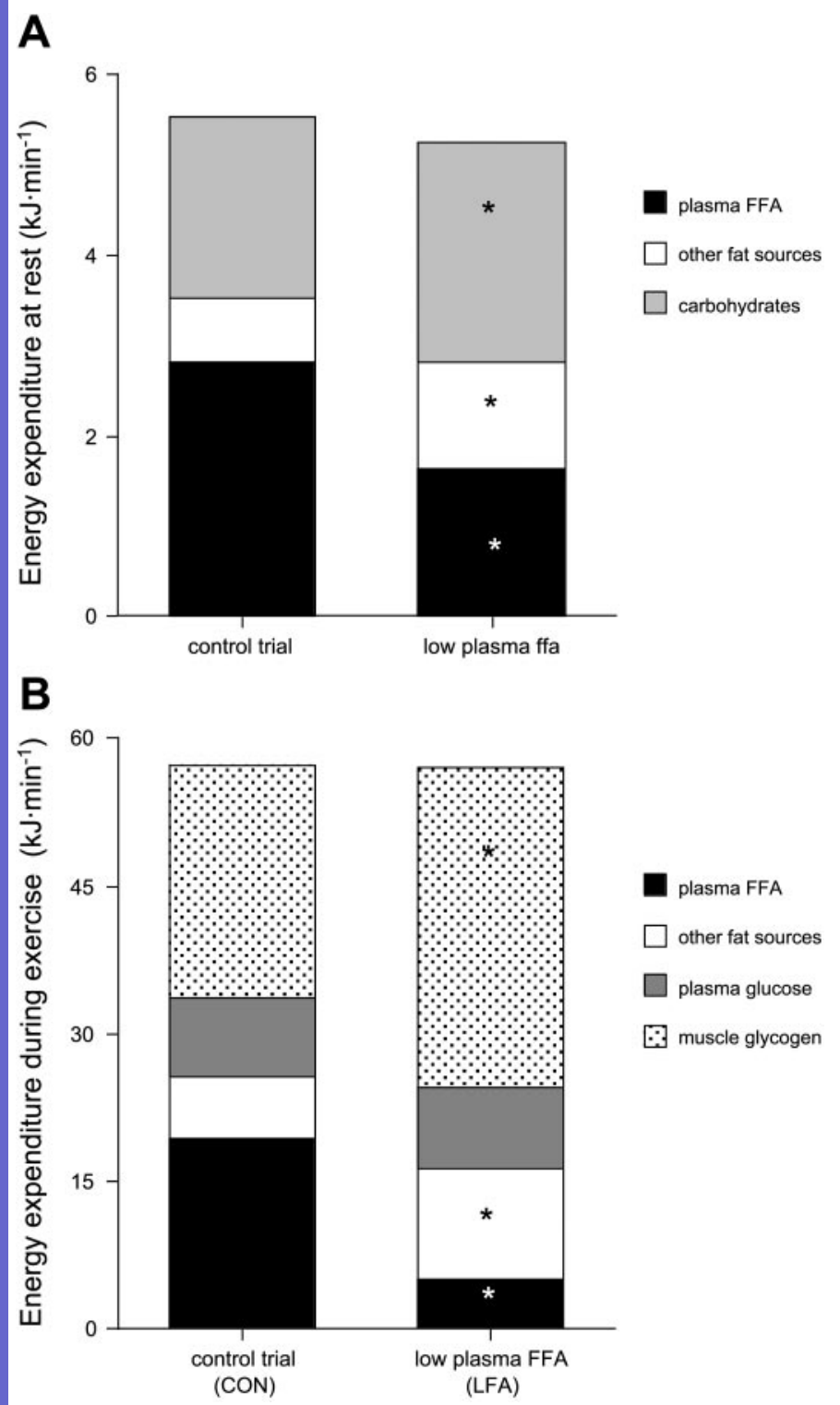

Fig. 4. Whole body substrate source utilization (in $\mathrm{kJ} / \mathrm{min}$ ) at rest $(A)$ and during the 2 nd h of exercise $(B)$ in CON and LFA trials. *Significant difference in plasma FFA, other fat sources, total carbohydrate, and/or plasma glucose $\mathrm{R}_{\mathrm{ox}}$ between trials $(P<0.05)$.

significantly greater in the LFA group than in the CON group $(4.5 \pm 0.7$ and $2.6 \pm 0.7 \%$ area lipid staining, respectively; $P<0.05)$. No changes in type II muscle fiber lipid content were observed between trials. However, within the LFA trial, type II fiber lipid content was significantly reduced after exercise $(P<0.05$; Fig. $6 B)$. The observed decreases in muscle lipid content were attributed to a significant decrease in both lipid droplet size and lipid droplet density (no. of droplets per area; $P<0.01$ ). Mixed muscle metabolite concentrations, as determined by biochemical analyses, are provided in Table 2 . Mixed muscle glycogen content decreased significantly in both trials $(P<0.01)$. The net difference between pre- and postexercise values averaged $305 \pm 56$ and $350 \pm 31 \mathrm{mmol} / \mathrm{kg}$ in the CON and LFA trials, respectively (NS).

Skeletal muscle $\alpha 2$-AMPK activity averaged $0.025 \pm 0.005$ and $0.025 \pm 0.007$ (rest), $0.025 \pm 0.004$ and $0.031 \pm 0.006$ (postexercise), and $0.031 \pm 0.009$ and $0.026 \pm 0.007 \mathrm{U} / \mathrm{mg}$ (2-h recovery) in the CON and LFA trials, respectively. Total AMPK activity averaged $0.049 \pm 0.009$ and $0.040 \pm 0.005$ (rest), $0.041 \pm 0.007$ and $0.037 \pm 0.011$ (postexercise), and $0.049 \pm 0.011$ and $0.041 \pm 0.003 \mathrm{U} / \mathrm{mg}$ (2-h recovery), respectively. No significant differences in $\alpha 2-A M P K$ and/or total AMPK activity were observed between the resting state, end of exercise, and 2-h recovery within or between groups. ACC phosphorylation status, expressed as the P-ACC/ACC ratio, averaged $1.55 \pm 0.34$ and $1.19 \pm 0.23$ (rest), $1.78 \pm 0.51$ and $2.12 \pm 0.66$ (postexercise), and $1.75 \pm 0.51$ and $1.45 \pm$ 0.39 (2-h recovery) in the CON and LFA trials, respectively. ACC phosphorylation status tended to be higher at the end of exercise in the LFA trial $(P=0.058)$, but no significant differences were observed between trials. The phosphorylation status of HSL at Ser $^{563}$ did not change over time and averaged $3.46 \pm 0.55$ and $2.97 \pm 0.52$ (rest), $3.27 \pm 0.50$ and $2.73 \pm$ 0.53 (postexercise), and $3.98 \pm 0.80$ and $2.65 \pm 0.62$ (2-h recovery) in the CON and LFA trials, respectively. Furthermore, HSL phosphorylation at $\operatorname{Ser}^{565}$ also did not change over time and averaged $1.17 \pm 0.08$ and $1.30 \pm 0.17$ (rest), $0.99 \pm$ 0.18 and $1.27 \pm 0.233$ (postexercise), and $1.19 \pm 0.09$ and $1.17 \pm 0.29$ (2-h recovery), respectively. The phosphorylation status of HSL at $\mathrm{Ser}^{563}$ or $\operatorname{Ser}^{565}$ did not differ between trials.

\section{DISCUSSION}

In the present study, acipimox administration is shown to effectively inhibit in vivo peripheral lipolysis, with plasma FFA $\mathrm{R}_{\mathrm{a}}$ being substantially decreased at rest and during exercise compared with normal, fasting conditions (Table 1 and Figs. 2 and 3). The latter substantially reduced systemic FFA availability, with plasma concentrations remaining well below baseline level. As such, plasma FFA concentrations were substantially reduced in the LFA vs. the CON trial (Fig. 2). The reduction in FFA availability substantially increased the estimated muscle TG use at rest (Fig. 4A). During exercise, the absence of a progressive increase in plasma FFA availability in the LFA trial was accompanied by muscle TG use being sustained (Fig. 5), resulting in higher estimated muscle TG and glycogen oxidation rates (Fig. 4B). In agreement with the tracer data, a greater net decline in type I muscle fiber lipid content was observed in the LFA vs. CON trial (Fig. 6). Although the exact mechanisms responsible remain to be resolved, this study provides definite evidence that plasma FFA availability regulates muscle TG and glycogen use.

Nicotinic acid (analogs) has often been used to study the effects of adipose tissue lipolytic inhibition on in vivo metabolism $(43,50,51,58)$. Nicotinic acid inhibits lipolysis by binding to HM74 receptors in human adipose tissue (49). Binding to these receptors results in a suppression of intracellular cAMP levels, with a subsequent decrease in cAMPdependent protein kinase activity, leading to a reduced association of HSL with its substrate in the lipid droplet of the adipocyte (6). These antilipolytic properties are specific for adipose tissue, as skeletal muscle does not express the HM74 receptor (49). Consequently, administration of nicotinic acid analogs like acipimox can be used to specifically inhibit adipose tissue lipolysis and reduce plasma FFA availability. In accordance with that, following acipimox administration we observed a massive reduction in plasma FFA $R_{a}$ at rest and 
A

\section{B}
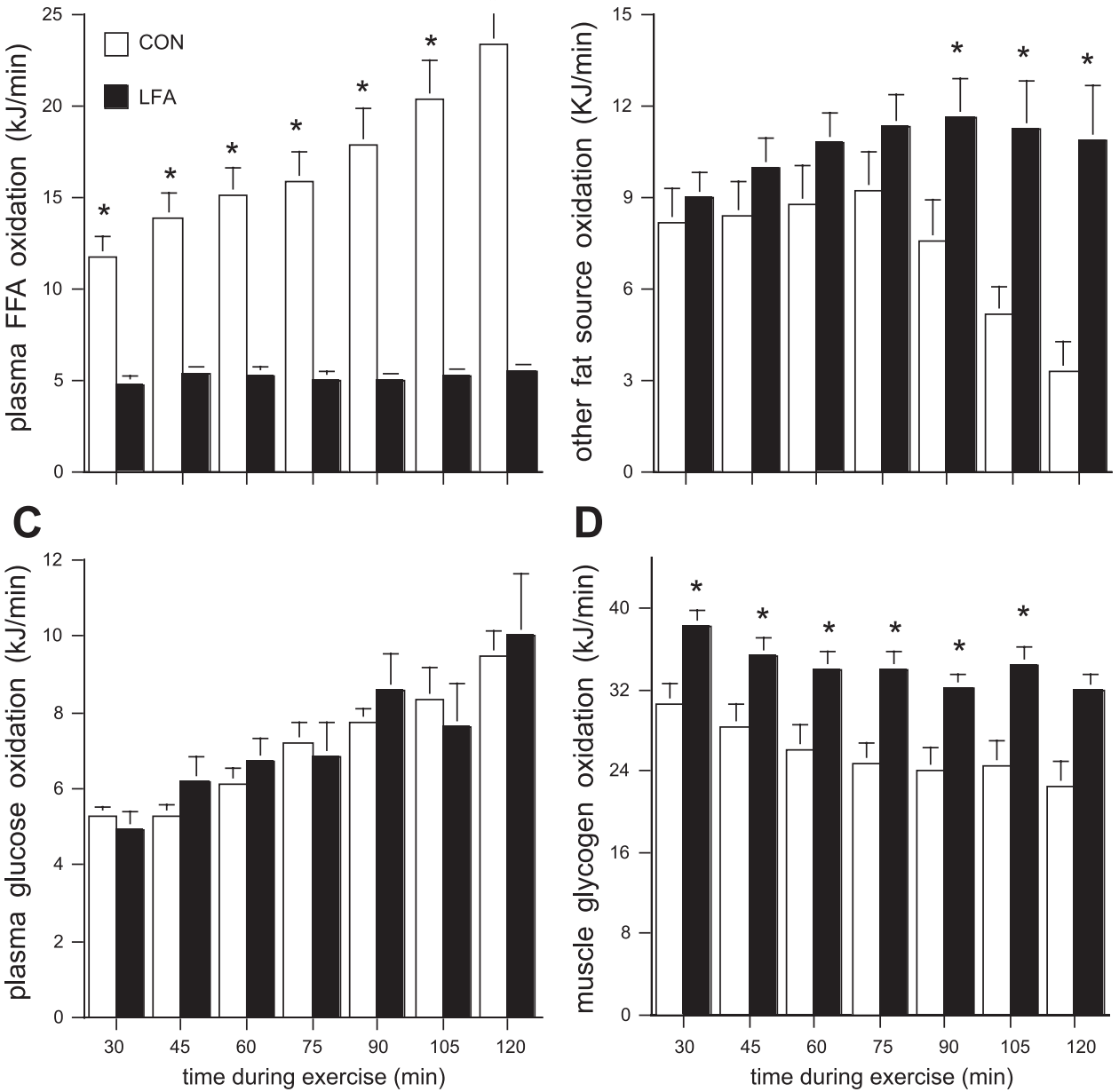

D

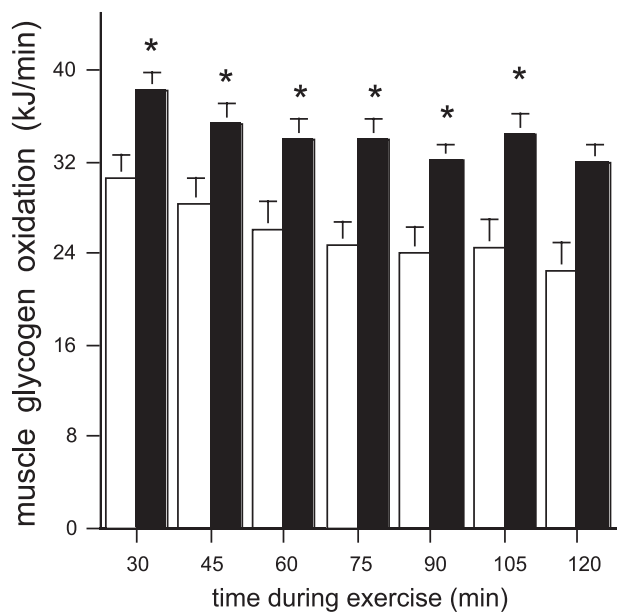

Fig. 5. Plasma FFA $(A)$, other fat sources $(B)$, plasma glucose $(C)$, and muscle glycogen $(D) \mathrm{R}_{\mathrm{ox}}$ over time during prolonged moderate-intensity exercise in $\mathrm{CON}$ and LFA trials. Data are means $\pm \mathrm{SE}$. * Significantly different between trials $(P<0.05)$. during exercise and subsequent recovery (Table 1), with FFA levels remaining well below baseline level (Fig. 2).

There has been much debate on the role of the IMTG pool as a substrate source at rest and/or during exercise $(52,57)$. Recently, we demonstrated that, besides plasma FFA, musclederived TG provides a substantial contribution to energy expenditure during exercise in trained males (54). In agreement, we demonstrated a $>60 \%$ net decline in type I muscle fiber lipid content in vastus lateralis muscle following $120 \mathrm{~min}$ of exercise (54). Furthermore, we observed a strong, progressive decline in the oxidation rate of muscle (plus lipoprotein)derived TG use during exercise. The latter correlated with the concomitant increase in plasma FFA $\mathrm{R}_{\mathrm{a}}$ and oxidation (54). Those findings confirmed earlier estimations $(40,41)$ as well as more recent observations (56) and support the contention that the progressive increase in peripheral lipolytic rate and the subsequent increase in plasma FFA availability suppress IMTG mobilization and/or oxidation. In agreement, Watt et al. (58) recently reported a greater net decline in mixed muscle $\mathrm{TG}$ content following nicotinic acid administration in a 3-h exercise trial. In the present study, we extended their findings by investigating whether inhibition of adipose tissue lipolysis could stimulate IMTG use at rest and/or prevent the progressive decline in IMTG utilization rate in time during exercise, resulting in a greater net decline in fiber type-specific IMTG content.
At rest, the threefold lower plasma FFA availability in the LFA trial (Fig. 2) strongly reduced plasma FFA oxidation rates (Table 1). The latter was compensated by a significant increase in the use of other fat sources as well as higher carbohydrate oxidation rates (Fig. 4A). These other fat sources are generally assumed to reflect the use of muscle-derived TG. However, the applied stable isotope methodology does not allow differentiation between muscle- and lipoprotein-derived TG use. Although the contribution of lipoprotein-derived TG oxidation to total energy turnover is generally assumed to be of little quantitative importance in an overnight-fasted state (52), it should be noted that specific tissues likely contribute more substantially to the use of lipoprotein-derived TG. Furthermore, plasma lipoprotein-derived TG use may likely be increased during exercise conditions. Our data imply that, during resting conditions, IMTG turnover is augmented when plasma FFA availability is reduced. As we applied a $\left[6,6-{ }^{2} \mathrm{H}_{2}\right]$ glucose tracer, plasma glucose oxidation rates could not be quantified at rest. The latter is due to the fact that, in contrast to exercise conditions, glucose $\mathrm{R}_{\mathrm{d}}$ does not match $\mathrm{R}_{\mathrm{ox}}$ during resting conditions (19). However, plasma glucose $\mathrm{R}_{\mathrm{a}}$ (hepatic glucose output) and $\mathrm{R}_{\mathrm{d}}$ (whole body glucose uptake) were not affected by these short-term alterations in plasma FFA availability. The latter is in accord with previous reports on acipimox administration, which reported no change in plasma glucose $\mathrm{R}_{\mathrm{d}}$ under basal resting conditions $(43,50)$. 

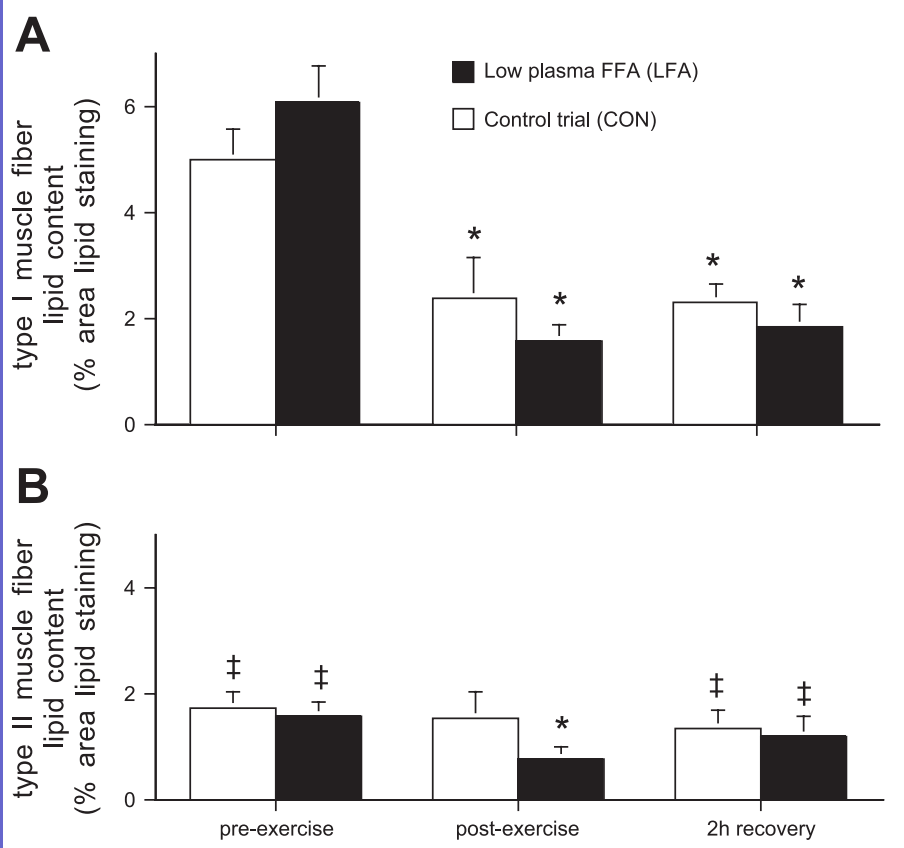

Fig. 6. Fiber type-specific intramyocellular lipid content (expressed as $\%$ area lipid stained) before exercise, immediately after exercise, and after $2 \mathrm{~h}$ of postexercise recovery as determined in type I $(A)$ or type II $(B)$ muscle fibers by use of semiquantitative fluoresence microscopy on Oil Red $\mathrm{O}$-stained muscle cross sections. Data provided are means \pm SE. *Significantly lower vs. preexercise values; $\ddagger$ significantly lower vs. type I muscle fibers $(P<0.05)$

During exercise, we observed a progressive increase in total fat $R_{o x}$ and a concomitant reduction in carbohydrate use under normal fasting conditions (CON). The greater fat $R_{o x}$ was fully accounted for by a progressive increase in plasma FFA $R_{a}, R_{d}$, and $R_{\mathrm{ox}}$ and was accompanied by a decline in the use of muscle (and lipoprotein)-derived TG (Table 1 and Figs. 4 and 5). The latter is in agreement with others' $(40,41,56,58)$ as well as our recent observations (54), showing a progressive decline in IMTG use during prolonged moderate-intensity exercise under fasting conditions in healthy men. In the present study, acipimox administration effectively inhibited adipose tissue lipolysis, thereby preventing the exercise-induced increase in plasma
FFA $R_{a}, R_{d}$, and $R_{o x}$ (Figs. 2 and 3). Consequently, no changes in substrate source utilization were observed throughout exercise in the LFA trial. As such, estimated IMTG $R_{\text {ox }}$ did not decline but remained elevated throughout the entire exercise trial (Fig. 5B). This led to substantially greater estimated IMTG utilization rates during the latter stages of prolonged exercise in the LFA trial (Figs. 4 and 5). In agreement with the isotope tracer data, a greater net decline in type I muscle fiber lipid content was observed in the LFA trial (Fig. 6). Similar to the resting data, plasma glucose disposal during exercise was not affected by the acute changes in FFA availability (Table 1 and Figs. 3-5). As such, the higher carbohydrate $\mathrm{R}_{\mathrm{ox}}$ in the LFA trial was entirely attributed to increased muscle glycogen use (Figs. 4 and 5). However, net changes in mixed muscle glycogen content in the biopsy samples did not significantly differ between trials and averaged $350 \pm 31$ and $305 \pm 56 \mathrm{mmol} / \mathrm{kg}$ in the LFA and CON trials, respectively (Table 2).

Our second aim was to elucidate the mechanisms responsible for the shift in substrate use. We speculated that a reduction in plasma FFA availability stimulates carbohydrate use via the Randle cycle (36). A reduction in FFA availability could stimulate muscle glycogen use by stimulating pyruvate dehydrogenase complex (PDC) activation (via a reduction in the mitochondrial acetyl-CoA/CoASH ratio) and increasing glycolytic flux (via a lower citrate concentration, thereby disinhibiting phosphofructokinase). Furthermore, the higher glycolytic flux would lead to a greater decrease in glucose 6-phosphate concentration, which would relieve its inhibition on glycogen phosphorylase and hexokinase activity. The latter would accelerate muscle glycogenolysis and/or upregulate plasma glucose uptake, respectively. Some evidence to support this contention was observed, as muscle samples obtained after exercise showed significantly lower ratios of acetyl-CoA/CoASH and acetylcarnitine/carnitine in the LFA vs. CON trial (Table 2). Furthermore, skeletal muscle citrate and glucose 6-phosphate levels tended to be lower in the LFA trial. Whereas estimated muscle glycogen use was indeed elevated in the LFA trial, plasma glucose uptake did not differ between trials.

The greater IMTG use during exercise in the LFA trial was entirely attributed to the absence of the progressive decline in IMTG use, as was observed in the CON trial (Fig. 5B).

Table 2. Muscle metabolites

\begin{tabular}{|c|c|c|c|c|c|c|}
\hline Free carnitine, $\mathrm{mmol} / \mathrm{kg}$ & $16.66 \pm 1.20$ & $9.35 \pm 1.08 *$ & $13.53 \pm 1.71$ & $17.29 \pm 0.57$ & $13.12 \pm 0.69^{* \dagger}$ & $17.46 \pm 0.75+\dagger$ \\
\hline LC-fatty acylcarnitine, $\mathrm{mmol} / \mathrm{kg}$ & $1.25 \pm 0.11$ & $1.40 \pm 0.08$ & $1.40 \pm 0.10$ & $1.33 \pm 0.06$ & $1.53 \pm 0.10$ & $1.49 \pm 0.11$ \\
\hline $\mathrm{CoASH}, \mu \mathrm{mol} / \mathrm{kg}$ & $104.7 \pm 7.9$ & $76.4 \pm 8.8^{*}$ & $77.5 \pm 7.0 *$ & $97.4 \pm 6.9$ & $92.5 \pm 5.0$ & $103.8 \pm 7.4 \dagger$ \\
\hline LC-fatty acyl-CoA, $\mu \mathrm{mol} / \mathrm{kg}$ & $10.43 \pm 1.37$ & $7.34 \pm 1.53$ & $7.41 \pm 1.51$ & $6.06 \pm 1.04 \dagger$ & $6.00 \pm 0.76$ & $5.05 \pm 0.82$ \\
\hline Citrate, $\mathrm{mmol} / \mathrm{kg}$ & $1.15 \pm 0.09$ & $2.12 \pm 0.29 *$ & $1.55 \pm 0.43 \$$ & $1.15 \pm 0.14$ & $1.48 \pm 0.13$ & $1.20 \pm 0.15$ \\
\hline Glucose 6-phosphate, $\mathrm{mmol} / \mathrm{kg}$ & $2.58 \pm 0.59$ & $1.86 \pm 0.37$ & $1.69 \pm 0.32$ & $3.92 \pm 1.06$ & $1.44 \pm 0.46$ & $2.92 \pm 0.93$ \\
\hline Glycogen, $\mathrm{mmol} / \mathrm{kg}$ & $586 \pm 50$ & $281 \pm 25^{*}$ & $290 \pm 36^{*}$ & $595 \pm 38$ & $245 \pm 43^{*}$ & $268 \pm 43^{*}$ \\
\hline Lactate, $\mathrm{mmol} / \mathrm{kg}$ & $3.10 \pm 0.71$ & $9.15 \pm 2.82$ & $4.76 \pm 2.02$ & $3.87 \pm 0.69$ & $7.37 \pm 3.03$ & $5.44 \pm 1.66$ \\
\hline
\end{tabular}

Values are means $\pm \mathrm{SE} ; n=10$. Intramuscular free carnitine, acetylcarnitine, long-chain (LC) fatty acylcarnitine, CoASH, LC-fatty acyl-CoA, acetyl-CoA, citrate, glucose 6-phosphate (p), glycogen, and lactate concentrations (expressed per kg dry muscle wt) before and after exercise and after $2 \mathrm{~h}$ of postexercise recovery in CON and LFA. Except for citrate concentrations, all concentrations have been normalized to total muscle creatine content. *Significantly different from resting values within each trial $(P<0.05)$; † significantly different between trials $(P<0.05)$; $\ddagger$ significantly different from postexercise values within each trial. 
Because muscle TG mobilization by HSL (24) represents the rate-limiting step in IMTG lipolysis, we investigated which mechanism(s) could be responsible for the increased activation of HSL in the LFA trial. We speculated that the reduced availability of plasma FFA could affect AMPK activation and the phosphorylation status of HSL at $\mathrm{Ser}^{565}$. Furthermore, previous studies (58) have reported a greater increase in plasma epinephrine concentrations during exercise after nicotinic acid administration, which could stimulate HSL activation by the phosphorylation of HSL at $\mathrm{Ser}^{563}$, acting through PKA. In addition, long-chain fatty acyl-CoA concentrations have been shown to inhibit HSL allosterically in adipose tissue (24) and muscle homogenates (24). A lower plasma FFA availability could reduce intramuscular long-chain fatty acyl-CoA concentrations and reduce allosteric inhibition of HSL. Despite our efforts to unravel the mechanism(s) responsible for the greater IMTG use in the LFA trial, we could not find evidence to support any of these mechanisms. Neither AMPK and $\alpha 2$ AMPK activity nor ACC phosphorylation status changed from rest to exercise and were not elevated after cessation of exercise in the LFA trial. These findings are in accord with Watt et al. (58), who also reported a greater net decline in mixed muscle lipid content following exercise when nicotinic acid was administered. In accord with the absence of changes in AMPK activity, no significant changes were observed in the phosphorylation status of ACC and the phosphorylation status of HSL at either $\mathrm{Ser}^{563}$ or $\mathrm{Ser}^{565}$. The latter findings are in line with recent observations by Roepstorff et al. (39) showing no changes in HSL phosphorylation at either $\mathrm{Ser}^{563}$ or Ser $^{565}$ after $60 \mathrm{~min}$ of moderate-intensity exercise under normal (nonglycogen-depleted) conditions despite a substantial increase in plasma epinephrine concentration. Furthermore, we did not observe a greater decline in intramuscular fatty acyl-CoA concentrations in the LFA trial (Table 2). The latter does not necessarily prove that reduced long-chain acyl-CoA concentrations are not responsible for the greater IMTG use under reduced plasma FFA availability, as compartmentalization of the long-chain fatty acyl-CoA pool has been suggested to occur (18). Consequently, although we clearly show that reduced plasma FFA availability stimulates IMTG use in vivo, the exact mechanism responsible remains to be elucidated.

The present study shows that inhibition of adipose tissue lipolysis using a nicotinic acid analog elevates intramuscular lipid and glycogen use. These findings could be of clinical relevance for the prevention and/or treatment of skeletal muscle insulin resistance. Depletion of both intramuscular lipid and glycogen content are associated with the exercise-induced increase in skeletal muscle insulin sensitivity $(52,62)$. In agreement, interventions known to improve insulin sensitivity, like dietary lipid withdrawal $(30)$, acute exercise $(30,54)$, and the use of thiazolidinediones (31) have all been associated with a concomitant reduction in IMTG content. Peroxisome proliferator-activated receptor- $\gamma$ (PPAR $\gamma$ ) agonists, like the thiazolidinediones, improve insulin sensitivity partly through lipid retention in adipose tissue, thereby stimulating the redistribution of TG from skeletal muscle and liver back to adipose tissue (28). Nicotinic acid (analogs) seems to act along the same paradigm. Similar to the metabolic consequences of excess muscle lipid accretion, increased muscle glycogen storage following overfeeding and/or inactivity has been reported to induce insulin resistance (29). In reverse, exercise stimulates muscle glycogen use (23) and augments insulin sensitivity, even in an insulin-resistant state $(35,61)$. The depletion of the muscle glycogen stores is associated with this exercise-induced increase in insulin sensitivity $(35,61)$, which can be maintained for up to $48 \mathrm{~h}(60)$ depending on the rate of muscle glycogen repletion $(7,9)$. Consequently, combined exercise and pharmacological interventions that elevate intramuscular lipid and/or glycogen use are likely more effective to maximize the exercise-induced increase in insulin sensitivity. The latter could be even more relevant in an insulin-resistant state, in which intramuscular lipid (52) and glycogen (4) use seem to be impaired.

In conclusion, oral administration of a nicotinic acid analog effectively suppresses adipose tissue lipolysis both at rest and during exercise conditions. The subsequent reduction in plasma FFA availability stimulates intramuscular lipid oxidation both at rest and during exercise. Inhibition of adipose tissue lipolysis during exercise provides an effective mechanistic approach to increase intramuscular lipid and glycogen use.

\section{ACKNOWLEDGMENTS}

We gratefully acknowledge the expert analytic assistance of Jos Stegen, Annemie Gijsen, Annita Rousseau, and Mia Meers as well as the enthusiastic support of the subjects who volunteered to participate in these trials. The monoclonal antibody A4.840 developed by Dr. Blau was obtained from the Developmental Studies Hybridoma Bank, developed under the auspices of the National Institute of Child Health and Human Development, and maintained by the University of Iowa, Department of Biological Science, Iowa City, IA 52242 .

\section{GRANTS}

M. Thomason-Hughes and D. G. Hardie are supported by grants from Diabetes, UK. L. J. C. van Loon was supported by a grant from the Netherlands Organization for Scientific Research.

\section{REFERENCES}

1. Adams JM, Pratipanawatr T, Berria R, Wang E, DeFronzo RA, Sullards MC, and Mandarino LJ. Ceramide content is increased in skeletal muscle from obese insulin-resistant humans. Diabetes 53: 25-31, 2004

2. Bergmayer HU. Methods of Enzymatic Analysis. New York: Academic, 1974

3. Boden G and Shulman GI. Free fatty acids in obesity and type 2 diabetes: defining their role in the development of insulin resistance and beta-cell dysfunction. Eur J Clin Invest 32, Suppl 3: 14-23, 2002.

4. Borghouts LB, Wagenmakers AJ, Goyens PL, and Keizer HA. Substrate utilization in non-obese Type II diabetic patients at rest and during exercise. Clin Sci 103: 559-566, 2002.

5. Cederblad G, Carlin JI, Constantin Teodosiu D, Harper P, and Hultman E. Radioisotopic assays of CoASH and carnitine and their acetylated forms in human skeletal muscle. Anal Biochem 185: 274-278, 1990.

6. Christie AW, McCormick DK, Emmison N, Kraemer FB, Alberti KG, and Yeaman SJ. Mechanism of anti-lipolytic action of acipimox in isolated rat adipocytes. Diabetologia 39: 45-53, 1996.

7. Derave W, Hansen BF, Lund S, Kristiansen S, and Richter EA. Muscle glycogen content affects insulin-stimulated glucose transport and protein kinase B activity. Am J Physiol Endocrinol Metab 279: E947E955, 2000.

8. Durante PE, Mustard KJ, Park SH, Winder WW, and Hardie DG. Effects of endurance training on activity and expression of AMP-activated protein kinase isoforms in rat muscles. Am J Physiol Endocrinol Metab 283: E178-E186, 2002.

9. Garcia-Roves PM, Han DH, Song Z, Jones TE, Hucker KA, and Holloszy JO. Prevention of glycogen supercompensation prolongs the increase in muscle GLUT4 after exercise. Am J Physiol Endocrinol Metab 285: E729-E736, 2003. 
10. Goodpaster B, Kelley D, Wing R, Meier A, and Thaete F. Effects of weight loss on regional fat distribution and insulin sensitivity in obesity. Diabetes 48: 839-847, 1999

11. Gutmann I and Wahlefeld AW. L-(+)-Lactate, determination with lactate dehydrogenase and NAD. In: Methods of Enzymatic Analysis (2nd ed.), edited by Bergmeyer HU. New York: Academic, 1974, p. $1464-1468$.

12. Hardie DG, Salt IP, and Davies SP. Analysis of the role of the AMP-activated protein kinase in the response to cellular stress. Methods Mol Biol 99: 63-74, 2000.

13. Harris RC, Hultman E, and Nordesjo LO. Glycogen, glycolytic intermediates and high-energy phosphates determined in biopsy samples of musculus quadriceps femoris of man at rest. Methods and variance of values. Scand J Clin Lab Invest 33: 109-120, 1974.

14. Hawley SA, Gadalla AE, Olsen GS, and Hardie DG. The antidiabetic drug metformin activates the AMP-activated protein kinase cascade via an adenine nucleotide-independent mechanism. Diabetes 51: 2420-2425, 2002

15. He J, Watkins S, and Kelley DE. Skeletal muscle lipid content and oxidative enzyme activity in relation to muscle fiber type in type 2 diabetes and obesity. Diabetes 50: 817-823, 2001.

16. Itani SI, Ruderman NB, Schmieder F, and Boden G. Lipid-induced insulin resistance in human muscle is associated with changes in diacylglycerol, protein kinase C, and IkappaB-alpha. Diabetes 51: 2005-2011, 2002.

17. Jensen MD. Fatty acid oxidation in human skeletal muscle. J Clin Invest 110: 1607-1609, 2002.

18. Jepson CA and Yeaman SJ. Inhibition of hormone-sensitive lipase by intermediary lipid metabolites. FEBS Lett 310: 197-200, 1992.

19. Jeukendrup AE, Raben A, Gijsen A, Stegen JH, Brouns F, Saris WH, and Wagenmakers AJ. Glucose kinetics during prolonged exercise in highly trained human subjects: effect of glucose ingestion. $J$ Physiol 515: 579-589, 1999.

20. Kelley DE, He J, Menshikova EV, and Ritov VB. Dysfunction of mitochondria in human skeletal muscle in type 2 diabetes. Diabetes 51: 2944-2950, 2002.

21. Kjaer M, Howlett K, Langfort J, Zimmerman-Belsing T, Lorentsen J, Bulow J, Ihlemann J, Feldt-Rasmussen U, and Galbo H. Adrenaline and glycogenolysis in skeletal muscle during exercise: a study in adrenalectomised humans. J Physiol 528: 371-378, 2000.

22. Krssak M, Falk Petersen K, Dresner A, DiPietro L, Vogel SM, Rothman DL, Roden M, and Shulman GI. Intramyocellular lipid concentrations are correlated with insulin sensitivity in humans: a ${ }^{1} \mathrm{H}$ NMR spectroscopy study. Diabetologia 42: 113-116, 1999.

23. Krssak M, Petersen KF, Bergeron R, Price T, Laurent D, Rothman DL, Roden M, and Shulman GI. Intramuscular glycogen and intramyocellular lipid utilization during prolonged exercise and recovery in man: a ${ }^{13} \mathrm{C}$ and ${ }^{1} \mathrm{H}$ nuclear magnetic resonance spectroscopy study. $J$ Clin Endocrinol Metab 85: 748-754, 2000.

24. Langfort J, Ploug T, Ihlemann J, Enevoldsen LH, Stallknecht B, Saldo M, Kjaer M, Holm C, and Galbo H. Hormone-sensitive lipase (HSL) expression and regulation in skeletal muscle. Adv Exp Med Biol 441: 219-228, 1998.

25. Langfort J, Ploug T, Ihlemann J, Holm C, and Galbo H. Stimulation of hormone-sensitive lipase activity by contractions in rat skeletal muscle. Biochem J 351: 207-214, 2000

26. Langfort J, Ploug T, Ihlemann J, Saldo M, Holm C, and Galbo H. Expression of hormone-sensitive lipase and its regulation by adrenaline in skeletal muscle. Biochem J 340: 459-465, 1999.

27. Malenfant P, Joanisse DR, Theriault R, Goodpaster BH, Kelley DE, and Simoneau JA. Fat content in individual muscle fibers of lean and obese subjects. Int J Obes Relat Metab Disord 25: 1316-1321, 2001

28. Mayerson AB, Hundal RS, Dufour S, Lebon V, Befroy D, Cline GW, Enocksson S, Inzucchi SE, Shulman GI, and Petersen KF. The effects of rosiglitazone on insulin sensitivity, lipolysis, and hepatic and skeletal muscle triglyceride content in patients with type 2 diabetes. Diabetes 51: 797-802, 2002.

29. Mott DM, Lillioja S, and Bogardus C. Overnutrition induced decrease in insulin action for glucose storage: in vivo and in vitro in man. Metabolism 35: $160-165,1986$.

30. Oakes ND, Bell KS, Furler SM, Camilleri S, Saha AK, Ruderman NB, Chisholm DJ, and Kraegen EW. Diet-induced muscle insulin resistance in rats is ameliorated by acute dietary lipid withdrawal or a single bout of exercise: parallel relationship between insulin stimulation of glucose uptake and suppression of long-chain fatty acyl-CoA. Diabetes 46: 2022 2028, 1997.

31. Oakes ND, Camilleri S, Furler SM, Chisholm DJ, and Kraegen EW. The insulin sensitizer, BRL 49653, reduces systemic fatty acid supply and utilization and tissue lipid availability in the rat. Metabolism 46: 935-942, 1997.

32. Pan DA, Lillioja S, Kriketos AD, Milner MR, Baur LA, Bogardus C, Jenkins AB, and Storlien LH. Skeletal muscle triglyceride levels are inversely related to insulin action. Diabetes 46: 983-988, 1997.

33. Peronnet $\mathbf{F}$ and Massicotte $\mathbf{D}$. Table of nonprotein respiratory quotient: an update. Can J Sport Sci 16: 23-29, 1991.

34. Perseghin G, Ghosh S, Gerow K, and Shulman GI. Metabolic defects in lean nondiabetic offspring of NIDDM parents: a cross-sectional study. Diabetes 46: 1001-1009, 1997.

35. Perseghin G, Price TB, Petersen KF, Roden M, Cline GW, Gerow K, Rothman DL, and Shulman GI. Increased glucose transport-phosphorylation and muscle glycogen synthesis after exercise training in insulinresistant subjects. $N$ Engl J Med 335: 1357-1362, 1996.

36. Randle PJ, Garland PB, Hales CN, and Newsholme EA. The glucosefatty acid cycle: its role in insulin sensitivity and the metabolic disturbances of diabetes mellitus. Lancet 1: 785-789, 1963.

37. Rasmussen BB, Holmbäck UC, Volpi E, Morio-Liondore B, PaddonJones D, and Wolfe RR. Malonyl coenzyme A and the regulation of functional carnitine palmitoyltransferase-1 activity and fat oxidation in human skeletal muscle. J Clin Invest 110: 1687-1693, 2002.

38. Reaven GM, Hollenbeck C, Jeng CY, Wu MS, and Chen YD. Measurement of plasma glucose, free fatty acid, lactate, and insulin for $24 \mathrm{~h}$ in patients with NIDDM. Diabetes 37: 1020-1024, 1988.

39. Roepstorff C, Vistisen B, Donsmark M, Nielsen JN, Galbo H, Green KA, Hardie DG, Wojtaszewski JF, Richter EA, and Kiens B. Regulation of hormone sensitive lipase activity and $\mathrm{Ser}^{563}$ and $\mathrm{Ser}^{565}$ phosphorylation in human skeletal muscle during exercise. $J$ Physiol 560: 551-562, 2004.

40. Romijn JA, Coyle EF, Sidossis LS, Gastaldelli A, Horowitz JF, Endert E, and Wolfe RR. Regulation of endogenous fat and carbohydrate metabolism in relation to exercise intensity and duration. Am J Physiol Endocrinol Metab 265: E380-E391, 1993.

41. Romijn JA, Coyle EF, Sidossis LS, Zhang XJ, and Wolfe RR. Relationship between fatty acid delivery and fatty acid oxidation during strenuous exercise. J Appl Physiol 79: 1939-1945, 1995.

42. Russell AP, Gastaldi G, Bobbioni-Harsch E, Arboit P, Gobelet C, Deriaz O, Golay A, Witztum JL, and Giacobino JP. Lipid peroxidation in skeletal muscle of obese as compared with endurance-trained humans: a case of good vs. bad lipids? FEBS Lett 551: 104-106, 2003.

43. Santomauro AT, Boden G, Silva ME, Rocha DM, Santos RF, Ursich MJ, Strassmann PG, and Wajchenberg BL. Overnight lowering of free fatty acids with Acipimox improves insulin resistance and glucose tolerance in obese diabetic and nondiabetic subjects. Diabetes 48: 1836-1841, 1999

44. Shulman GI. Cellular mechanisms of insulin resistance. J Clin Invest 106: 171-176, 2000.

45. Sidossis LS, Coggan AR, Gastaldelli A, and Wolfe RR. A new correction factor for use in tracer estimations of plasma fatty acid oxidation. Am J Physiol Endocrinol Metab 269: E649-E656, 1995.

46. Siri WE. The gross composition of the body. Adv Biol Med Physiol 4: $238-280,1956$.

47. Sugden C, Crawford RM, Halford NG, and Hardie DG. Regulation of spinach SNF1-related (SnRK1) kinases by protein kinases and phosphatases is associated with phosphorylation of the T loop and is regulated by 5'-AMP. Plant J 19: 433-439, 1999.

48. Thamer C, Machann J, Bachmann O, Haap M, Dahl D, Wietek B, Tschritter O, Niess A, Brechtel K, Fritsche A, Claussen C, Jacob S, Schick F, Haring HU, and Stumvoll M. Intramyocellular lipids: anthropometric determinants and relationships with maximal aerobic capacity and insulin sensitivity. J Clin Endocrinol Metab 88: 1785-1791, 2003.

49. Tunaru S, Kero J, Schaub A, Wufka C, Blaukat A, Pfeffer K, and Offermanns S. PUMA-G and HM74 are receptors for nicotinic acid and mediate its anti-lipolytic effect. Nat Med 9: 352-355, 2003.

50. Vaag A, Skott P, Damsbo P, Gall MA, Richter EA, and Beck-Nielsen H. Effect of the antilipolytic nicotinic acid analogue acipimox on wholebody and skeletal muscle glucose metabolism in patients with non-insulindependent diabetes mellitus. J Clin Invest 88: 1282-1290, 1991.

51. Vaag AA and Beck-Nielsen H. Effects of prolonged Acipimox treatment on glucose and lipid metabolism and on in vivo insulin sensitivity in 
patients with non-insulin dependent diabetes mellitus. Acta Endocrinol 127: 344-350, 1992.

52. Van Loon LJC. Use of intramuscular triacylglycerol as a substrate source during exercise in humans. $J$ Appl Physiol 97: 1170-1187, 2004.

53. Van Loon LJC, Koopman R, Manders R, van der Weegen W, van Kranenburg GP, and Keizer HA. Intramyocellular lipid content in type 2 diabetes patients compared to overweight sedentary men and highly trained endurance athletes. Am J Physiol Endocrinol Metab 287: E558E565, 2004

54. Van Loon LJC, Koopman R, Stegen JH, Wagenmakers AJ, Keizer HA, and Saris WH. Intramyocellular lipids form an important substrate source during moderate intensity exercise in endurance-trained males in a fasted state. J Physiol 553:611-625, 2003.

55. Van Loon LJC, Schrauwen-Hinderling VB, Koopman R, Wagenmakers AJM, Hesselink MK, Schaart G, Kooi ME, and Saris WHM. Influence of prolonged endurance cycling and recovery diet on intramuscular triglyceride content in humans. Am J Physiol Endocrinol Metab 285: E804-E811, 2003.

56. Watt MJ, Heigenhauser GJ, Dyck DJ, and Spriet LL. Intramuscular triacylglycerol, glycogen and acetyl group metabolism during $4 \mathrm{~h}$ of moderate exercise in man. J Physiol 541: 969-978, 2002.

57. Watt MJ, Heigenhauser GJ, and Spriet LL. Intramuscular triacylglycerol utilization in human skeletal muscle during exercise: is there a controversy? J Appl Physiol 93: 1185-1195, 2002.

58. Watt MJ, Holmes AG, Steinberg GR, Mesa JL, Kemp BE, and Febbraio MA. Reduced plasma FFA availability increases net triacyl- glycerol degradation, but not GPAT or HSL activity, in human skeletal muscle. Am J Physiol Endocrinol Metab 287: E120-E127, 2004.

59. Watt MJ, Stellingwerff T, Heigenhauser GJ, and Spriet LL. Effects of plasma adrenaline on hormone-sensitive lipase at rest and during moderate exercise in human skeletal muscle. J Physiol 550: 325-332, 2003.

60. Wojtaszewski JF, Hansen BF, Gade Kiens B, Markuns JF, Goodyear LJ, and Richter EA. Insulin signaling and insulin sensitivity after exercise in human skeletal muscle. Diabetes 49: 325-331, 2000.

61. Wojtaszewski JF, Hansen BF, Kiens B, and Richter EA. Insulin signaling in human skeletal muscle: time course and effect of exercise. Diabetes 46: 1775-1781, 1997.

62. Wojtaszewski JF, Jorgensen SB, Frosig C, MacDonald C, Birk JB, and Richter EA. Insulin signalling: effects of prior exercise. Acta Physiol Scand 178: 321-328, 2003.

63. Wolfe RR and Jahoor F. Recovery of labeled $\mathrm{CO}_{2}$ during the infusion of C1 vs C2 labeled acetate: implications for tracer studies of substrate oxidation. Am J Clin Nutr 51: 248-252, 1990.

64. Woods A, Salt I, Scott J, Hardie DG, and Carling D. The alpha1 and alpha2 isoforms of the AMP-activated protein kinase have similar activities in rat liver but exhibit differences in substrate specificity in vitro. FEBS Lett 397: 347-351, 1996.

65. Yu C, Chen Y, Cline GW, Zhang D, Zong H, Wang Y, Bergeron R, Kim JK, Cushman SW, Cooney GJ, Atcheson B, White MF, Kraegen EW, and Shulman GI. Mechanism by which fatty acids inhibit insulin activation of insulin receptor substrate-1 (IRS-1)-associated phosphatidylinositol 3-kinase activity in muscle. J Biol Chem 277: 50230-50236, 2002. 